\title{
Proposal for a New Hierarchic Classification System, Actinobacteria classis nov.
}

\author{
ERKO STACKEBRANDT, ${ }^{*}$ FRED A. RAINEY, AND NAOMI L. WARD-RAINEY \\ DSMZ-Deutsche Sammlung von Mikroorganismen und Zellkulturen GmbH, 38124 Braunschweig, Germany
}

\begin{abstract}
A new hierarchic classification structure for the taxa between the taxonomic levels of genus and class is proposed for the actinomycete line of descent as defined by analysis of small subunit (16S) rRNA and genes coding for this molecule (rDNA). While the traditional circumscription of a genus of the actinomycete subphylum is. by and large in accord with the $16 \mathrm{~S} \mathrm{rRNA} / \mathrm{rDNA}$-based phylogenetic clustering of these organisms, most of the higher taxa proposed in the past do not take into account the phylogenetic clustering of genera. The rich chemical, morphological and physiological diversity of phylogenetically closely related genera makes the description of families and higher taxa so broad that they become meaningless for the description of the enclosed taxa. Here we present a classification system in which phylogenetically neighboring taxa at the genus level are clustered into families, suborders, orders, subclasses, and a class irrespective of those phenotypic characteristics on which the delineation of taxa has been based in the past. Rather than being based on a listing of a wide array of chemotaxonomic, morphological, and physiological properties, the delineation is based solely on $16 \mathrm{~S}$ rDNA/rRNA sequence-based phylogenetic clustering and the presence of taxon-specific $16 \mathrm{~S}$ rDNA/RNA signature nucleotides.
\end{abstract}

In their publication "On the nature of global classification," Wheelis et al. (177) based the definition of higher taxa on the molecular level of universally homologous functions. This statement is derived from the high correlation of genealogical trees inferred from several such molecules, e.g., genes coding for 16S rRNA (16S rDNA) (179), 23S rDNA (96), elongation factors involved in the translation process, and the $\beta$-subunit of ATPase (97). The authors (177) stress that a basic requirement of a global classification is uniformity in methods and characteristics used in defining and ranking taxa. Nonhomologous characteristics, on the other hand, may be useful in confirming the molecular groupings. Application of this classification strategy led to the description of domains for the three highest taxa recognized today, the Archaea, Bacteria, and Eucarya (180). As a consequence of the description of kingdoms for the major lineages within the domain Eucarya (plants, animals, fungi, and protozoa), Woese et al. (180) described the two main lineages within the domain Archaea as the kingdom Crenarchaeota and the kingdom Euryarchaeota.

Within the domain Bacteria, more than 15 lineages, which in phylogenetic uniqueness and ancestry are comparable to the archaeal kingdoms, have been identified. The taxonomic rank of kingdom has not yet been proposed for any of these lineages. The taxon class Proteobacteria has been proposed for a phylogenetically broad cluster of gram-negative genera, and several orders have been described for some of the phylogenetic lineages that emerged from the comparison of evolutionarily conserved macromolecules; e.g., Aquificales (15), Thermotogales (67), Verrucomicrobiales (173), and Planctomycetales (138). These phylogenetically coherent taxa are now used side by side with higher taxa that were described at the beginning of the pre-molecular era, i.e., before or around 1984. While the phylogenetic coherence of the division Firmacutes (53), the class Mollicutes, and the orders Chlamydiales, Spirochaetales, and Myxobacterales were by and large confirmed following $16 \mathrm{~S}$

\footnotetext{
* Corresponding author. Mailing address: DSMZ-Deutsche Sammlung von Mikroorganismen und Zellkulturen $\mathrm{GmbH}$, Mascheroder Weg 1b, 38124 Braunschweig, Germany. Phone: 49531 2616 352. Fax: 495312616 418. E-mail: erko@gbf-braunschweig.de.
}

rDNA analyses of their members, the majority of higher taxa represent a collection of phylogenetically diverse families and genera. Examples are the classes Actinomycetes (81) and Photobacteria (53) and the orders Clostridiales and Bacillales (119), which need to be redefined in order to make classification consistent with phylogenetic structure.

One of the main lines of descent within the domain Bacteria includes a wide range of morphologically diverse organisms, most of which, on the basis of a gram-positive staining reaction, can be considered members of the division Firmacutes (53). This lineage comprises organisms with a DNA base composition which generally is above $50 \mathrm{~mol} \% \mathrm{G}+\mathrm{C}$ (with a few exceptions) and includes representatives of the class Actinomycetes (81), the orders Actinomycetales (13) and Micrococcales (118), the tribes Brevibactereae and Micrococceae (120), and several families of the order Actinomycetales as well as additional organisms which were identified as members of this lineage by phylogenetic analyses. This lineage encompasses a wide range of bacteria that irrespective of Gram stain reaction, base composition of DNA, morphology, chemotaxonomic properties, and other characteristics used to delineate bacterial taxa in the past, have a common ancestry (Fig. 1).

The modern era in the classification of organisms that are proposed as members of the class Actinobacteria has its origin in three sources: firstly, the establishment of chemotaxonomy that detects differences in the chemical composition of cell constituents such as peptidoglycan, polar lipids and fatty acids, isoprenoid quinones, cytochromes, and the base composition of DNA; secondly, the introduction of DNA-DNA reassociation experiments that measure the gross similarities between single-stranded DNA of strains of closely related species (144); and thirdly, the determination of $16 \mathrm{~S}$ rRNA and rDNA sequence similarities, which reveals the extent of sequence variation among strains at all levels of relatedness (148). Each of these approaches has contributed to the success of a classification strategy which has been termed polyphasic by Colwell (34).

Although the appropriate methods have been available for decades, it took about 30 years to achieve a comprehensive overview of the relatedness among actinomycete bacteria that would allow a proposal for a unified classification system. The 


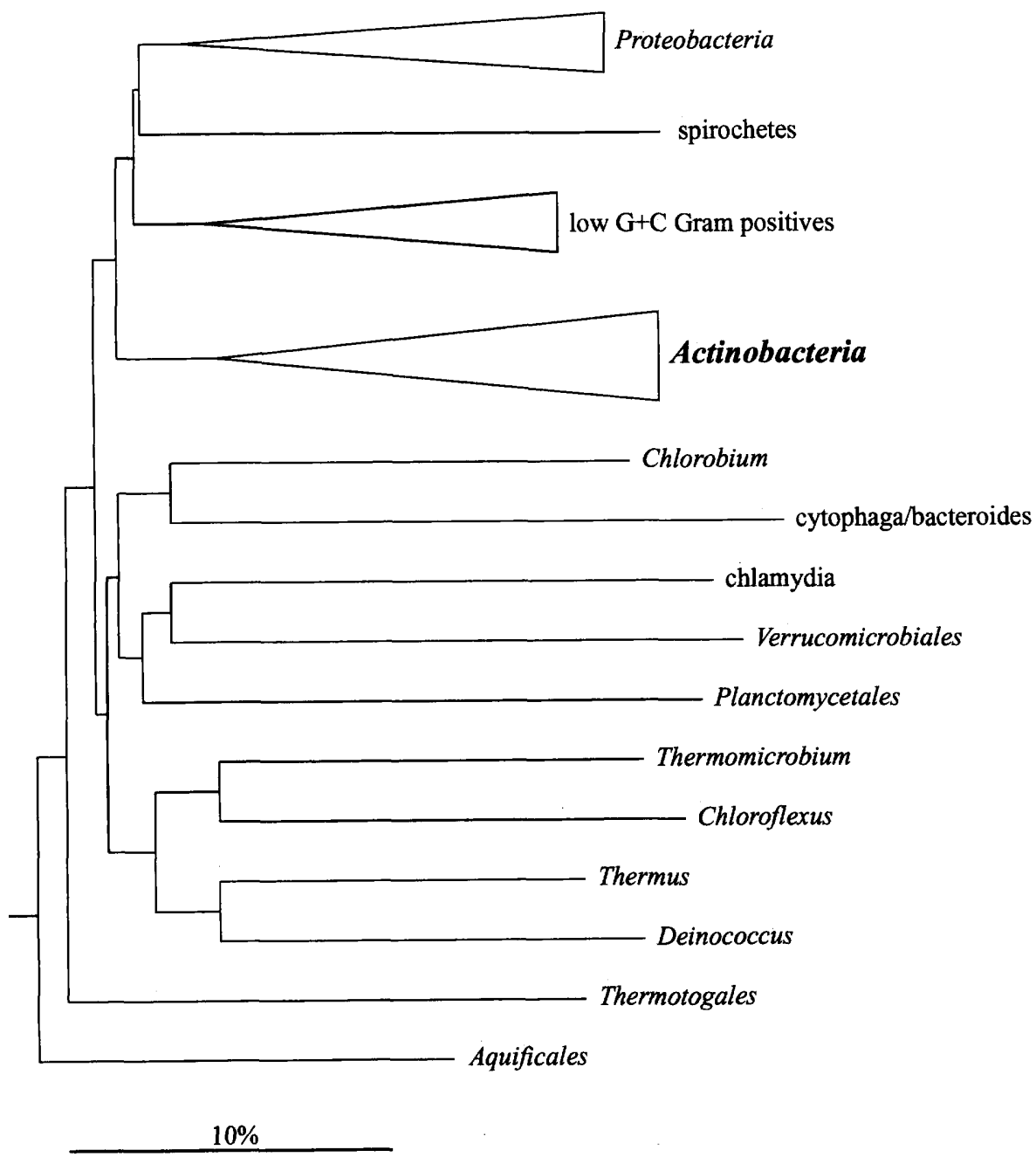

FIG. 1. Dendrogram of $16 \mathrm{~S}$ rDNA/rRNA relationships showing the phylogenetic position of the proposed class Actinobacteria within the domain Bacteria. Sequences of Archaea were used to root the dendrogram. The recovery of the main lines of descent is as published by Woese (179). The scale bar represents 10 nucleotide substitutions per 100 nucleotides.

reasons were manifold. The most obvious one is the late introduction of 16S rRNA/DNA sequence analysis that, better than any other taxonomic method, places an organism in the framework of phylogenetic relationships. The restricted information on the degree of relatedness obtained by DNA-DNA reassociation studies (143) only allowed analysis of highly related species, while elucidation of more remote relationships had to wait for analysis of conservative genes. Another reason was the tremendous amount of work needed to analyze the phylogenetic relatedness of the type strains of several hundred species which in the end led to the recognition of those properties at the epigenetic level that could be used to unambiguously circumscribe species at the genus level.

\section{MATERIALS AND METHODS}

Phylogenetic analyses. As this publication reviews published data, no emphasis is placed on methods. Rather we refer to relevant publications, most of which contain original or cited data on phylogeny, chemotaxonomy, and other phenotypic data used in the classification of actinomycetes above the species level.

An alignment of all 16S rRNA/DNA sequences currently available for members of the actinomycete lineage was created by using the ae 2 editor (99). The sequences included in this alignment were obtained from the Ribosomal Database Project (99) and the ARB package (a software environment for sequence data) (156) as well as our own entries. The 16S rRNA/DNA sequences were manually aligned to provide a secondary structure-based optimal alignment. The best sequences available were chosen in all cases, but due to the fact that many of the actinomycete reference sequences obtained from the databases are partial sequences consisting of fewer than 1,300 nucleotides, an ideal data set could not be constructed.

The complete data set used for the analyses described in this study contained information on more than 1,000 unambiguous nucleotide positions present in all sequences between positions 150 and 1400 (Escherichia coli sequence [11]) Individual data sets, which in many cases comprised more than 1,300 nucleotides, were used for the determination of the relationships within the groups of the proposed taxonomic structure of the actinomycetes. The data set consisting of the type strains of the type species of the genera included in this study can be requested from the authors. The following genera have either not yet been investigated by $16 \mathrm{~S}$ rDNA sequence analysis and their phylogenetic affiliation remains undetermined or their exact phylogenetic position is unclear: Actinocorallia (68), Actinokineospora (64), Excellospora (1), Kineococcus (186), Kineosporia (112), and Micropolyspora (93).

For the reconstruction of the phylogenetic dendrograms, evolutionary distances were calculated by the method of Jukes and Cantor (70). Phylogenetic dendrograms were reconstructed by using treeing algorithms contained in the PHYLIP package (46) and the ARB package (156). The robustness of tree topologies was evaluated by bootstrap analyses (45) of the neighbor-joining (136) data by performing 1,000 resamplings. The phylogenetic dendrograms presented in many cases represent a general overview at the higher-taxon level and do not show the individual branching order at the genus and species level. These lowertaxon branching orders are susceptible to changes depending on the data set used in the analysis, but the compositions of taxa above the genus level will not be affected. 


\title{
Class Actinobacteria
}

\author{
Subclass Acidimicrobidae \\ Order Acidimicrobiales \\ Subclass Rubrobacteridae \\ Order Rubrobacterales \\ Family Acidimicrobiaceae \\ Subclass Coriobacteridae \\ Subclass Sphaerobacteridae \\ Subclass Actinobacteridae \\ Order Sphaerobacterales Family Sphaerobacteraceae \\ Order Actinomycetales
}

\begin{tabular}{|c|c|c|c|c|}
\hline $\begin{array}{l}\text { Suborder } \\
\text { Actinomycineae }\end{array}$ & $\begin{array}{l}\text { Suborder } \\
\text { Micrococcineae }\end{array}$ & $\begin{array}{l}\text { Suborder } \\
\text { Corynebacterineae }\end{array}$ & $\begin{array}{l}\text { Suborder } \\
\text { Micromonosporineae }\end{array}$ & $\begin{array}{l}\text { Suborder } \\
\text { Propionibacterineat }\end{array}$ \\
\hline $\begin{array}{l}\text { Family } \\
\text { Actinomycetaceae }\end{array}$ & \begin{tabular}{|l|} 
Families \\
Micrococcaceae \\
Brevibacteriaceae \\
Cellulomonadaceae \\
Dermabacteraceae \\
Dermatophilaceae \\
Intrasporangiaceae \\
Jonesiaceae \\
Microbacteriaceae \\
Promicromonosporaceae \\
\end{tabular} & \begin{tabular}{|l|} 
Families \\
Corynebacteriaceae \\
Dietziaceae \\
Gordoniaceae \\
Mycobacteriaceae \\
Nocardiaceae \\
Tsukamurellaceae
\end{tabular} & \begin{tabular}{|l|} 
Family \\
Micromonosporaceae
\end{tabular} & \begin{tabular}{|l|} 
Families \\
Propionibacteriaceae \\
Nocardioidaceae \\
\end{tabular} \\
\hline $\begin{array}{l}\text { Suborder } \\
\text { Pseudonocardineae }\end{array}$ & $\begin{array}{l}\text { Suborder } \\
\text { Streptomycineae }\end{array}$ & $\begin{array}{l}\text { Suborder } \\
\text { Streptosporangineae }\end{array}$ & $\begin{array}{l}\text { Suborder } \\
\text { Frankineae }\end{array}$ & $\begin{array}{l}\text { Suborder } \\
\text { Glycomycineae }\end{array}$ \\
\hline $\begin{array}{l}\text { Family } \\
\text { Pseudonocardiaceae }\end{array}$ & $\begin{array}{l}\text { Family } \\
\text { Streptomycetaceae }\end{array}$ & $\begin{array}{l}\text { Families } \\
\text { Streptosporangiaceae } \\
\text { Nocardiopsaceae } \\
\text { Thermomonosporaceae }\end{array}$ & $\begin{array}{l}\text { Families } \\
\text { Frankiaceae } \\
\text { Acidothermaceae } \\
\text { Geodermatophilaceae } \\
\text { Microsphaeraceae } \\
\text { Sporichthyaceae }\end{array}$ & $\begin{array}{l}\text { Family } \\
\text { Glycomycetaceae }\end{array}$ \\
\hline
\end{tabular}

Order Bifidobacteriales Family Bifidobacteriaceae

FIG. 2. Proposed hierarchic classification system of the class Actinobacteria based on the phylogenetic analyses of the 16S rDNA/rRNA sequence data.

\section{RESULTS AND DISCUSSION}

The basis for the proposal of a novel hierarchic structure (Fig. 2) for the phylogenetically coherent group of actinomycete bacteria and relatives is membership of the same phylogenetic group which was formerly described as a $16 \mathrm{~S}$ rRNA subdivision or subphylum of the gram-positive bacteria. The common ancestry of the actinomycetes proper and the second subdivision of gram-positive bacteria, defined by clostridia, bacilli, and their relatives, has not yet been convincingly demonstrated by $16 \mathrm{~S}$ rDNA analyses. However, sequence analyses of glutamine synthetase, glutamate dehydrogenase, and the heat shock protein HSP70 reveal a common ancestry of the grampositive bacteria $(59,60)$. The phylogenetic coherence of these organisms supports the description of a kingdom for the Firmacutes which would contain two or more classes, one of which embraces the actinomycetes proper. If the results of future studies were to unambiguously demonstrate the common ancestry of members of the two subphyla they could be united under the umbrella of a common higher taxon, the kingdom.

Membership of a new strain to the class Actinobacteria is indicated by $16 \mathrm{~S}$ rDNA sequence similarity values above $80 \%$ as determined by comparison of almost-complete $16 \mathrm{~S}$ rDNA sequences of the new strain and the most deeply branching members of the class, such as Rubrobacter radiotolerans, Acidimicrobium ferrooxidans, or Coriobacterium glomerans, and the presence of signature nucleotides. We are aware that the phylogenetic tree, upon which the conclusions outlined below are based, is a mathematical model of how bacterial evolution occurs. Signature nucleotides are derivatives of the classification process; i.e., signatures are determined for those organisms that are contained within a particular data set. It is also known that a significant increase in species numbers in any of the phylogenetic lineages may lead to a decrease in the number of signatures as the $16 \mathrm{~S}$ rDNA of more slowly or more rapidly evolving strains may not contain the signature. It is hoped that this proposal will stimulate analyses of other conservative genes from organisms that cluster together by $16 \mathrm{~S}$ rDNA analyses, so that taxonomic information is provided from additional, independently selected genes and properties and the hierarchic structure proposed here can be tested.

The signatures given below for the higher taxa were chosen for their presence in more than $95 \%$ of the members of the respective taxon. The signature pattern for monospecific families must be considered tentative. It should be mentioned that the pattern of signature nucleotides, but not necessarily each individual nucleotide, is indicative of the membership of a taxon to a higher taxon. Bootstrap values (not shown) were determined for the branching points shown in Fig. 3 and were higher than $90 \%$ in only a few cases, indicating a lack of statistical significance of the respective branching points. Despite the finding that the majority of branching points are not supported by high bootstrap values, the orders, suborders, and families described previously and below are consistently recoverable from phylogenetic analyses. The lack of high bootstrap 


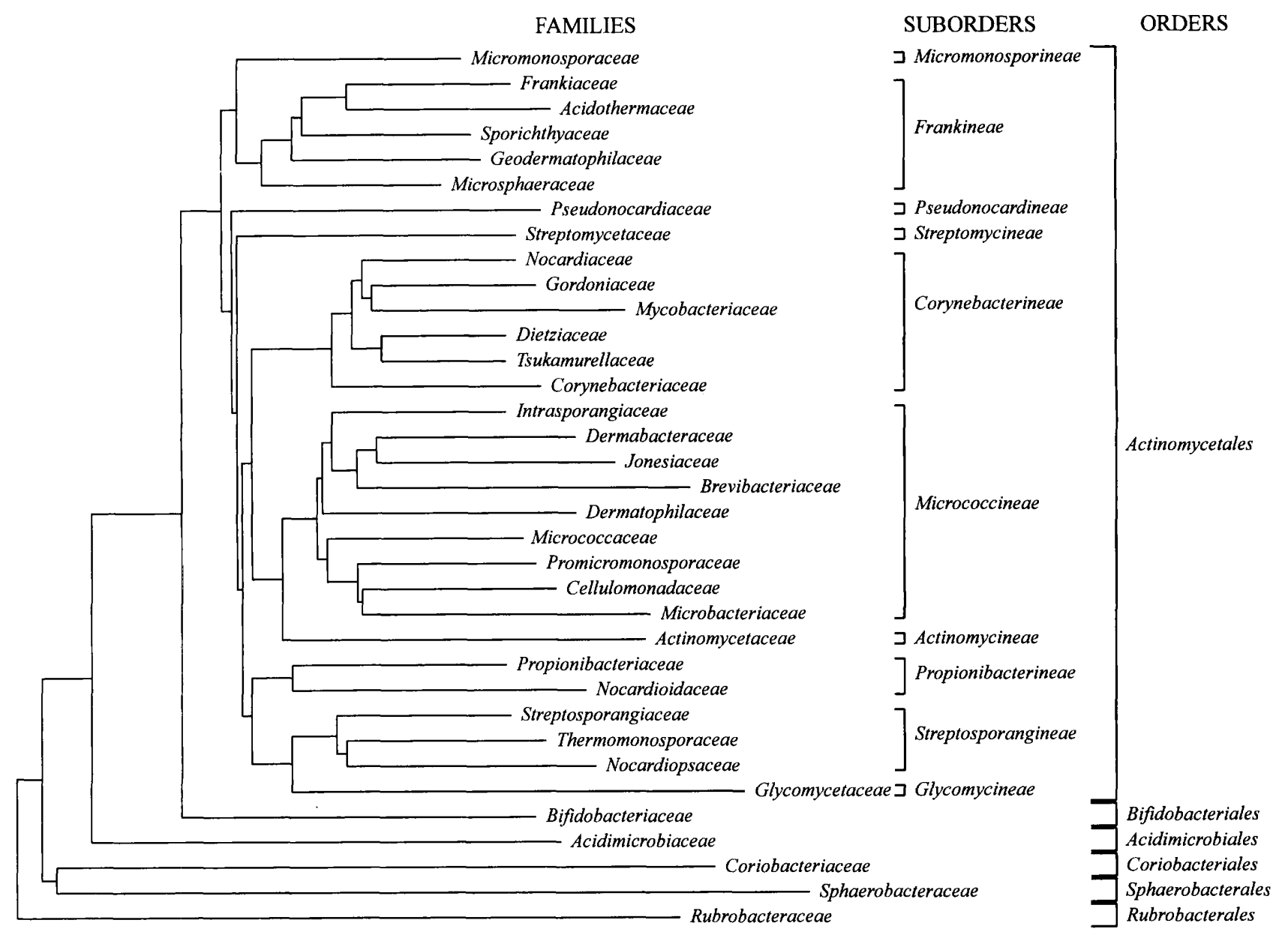

FIG. 3. Intraclass relatedness of Actinobacteria showing the presence of six orders as well as the 10 suborders of the order Actinomycetales based upon $16 \mathrm{~S}$ rDNA/rRNA sequence comparison. The phylogenetic relatedness of the families of the class Actinobacteria is outlined. The scale bar represents 5 nucleotide substitutions per 100 nucleotides.

values is probably due to the small differences in the primary structure of $16 \mathrm{~S}$ rDNA of members of most of the neighboring families. Many of the signature nucleotides and idiosyncrasies are located in highly variable and hypervariable regions of the $16 \mathrm{~S}$ rDNA molecule, which means that dendrograms of relatedness are mostly derived from nucleotide positions that are subject to changes. Also, low bootstrap values are found when the radiation of lineages occurs within a short evolutionary time span, like those found for the radiation of most suborders of the order Actinomycetales. Nevertheless, the separate branching of these suborders is found in any of the trees generated, irrespective of the algorithm used. This means that even if the branching points of taxa above the genus level change within the narrow margin at which the higher taxa separate from each other, their phylogenetic uniqueness remains unchanged and their affiliation to the next higher taxon will not be greatly affected. As indicated above, the patterns of signature nucleotides may need to be emended when analysis of novel members of the families indicates the necessity for doing so. In this respect, the taxa defined by molecular data reflect the most recent state-of-the-art insights into molecular systematics. A strategy that could be used in the future to decide whether or not a member of a novel genus could be considered a member of a known or a novel family and/or any other of the defined higher ranks would include (i) generation of a high-quality, complete or almost-complete $16 \mathrm{~S}$ rDNA sequence, (ii) proper alignment of the sequence to reference sequences of the same quality, (iii) determination of the phylogenetic position, and (iv) checking for the presence of signature nucleotides as given below for members of the taxon with which the organism groups. If the vast majority of the signature nucleotides match those previously defined for the nearest neighbors, the organism can be considered a member of this taxon. If, however, several signature nucleotides are missing, this genus most likely represents a novel family for which a novel set of signature nucleotides must be defined.

The proposal presented here does not change the current descriptions of species and genera, which are in most cases based upon morphological, chemotaxonomic, and physiological characteristics. These taxa, which provide the working basis for taxonomists, have been revised in the past 20 years to constitute phylogenetically coherent taxonomic units. In contrast, the descriptions of taxa above the genus level have a more broadly based description to incorporate the characteristics of the individual genera contained therein. The description of the family Micromonosporaceae should serve as an example (78), and other examples include the families Propionibacteriaceae and Pseudonocardiaceae. 
Class Actinobacteria classis nov., Stackebrandt, Rainey, and Ward-Rainey. Actinobacteria (Ac.ti.no.bac.te'ri.a. Gr. n. actis, actinis, a ray, beam; Gr. dim. n. bakterion, a small rod; -ia, proposed ending to denote class; Actinobacteria, actinomycete group of bacteria of diverse morphological properties). The class is definable in phylogenetic terms as derived from the analysis of macromolecules of universally homologous functions. Strains of the class Actinobacteria can consistently be recovered as members of the same phylogenetic lineage, revealing $>80 \% 16 \mathrm{~S}$ rDNA/rRNA sequence similarity among each other (Fig. 1), and the presence of the following signature nucleotides in the $16 \mathrm{~S} \mathrm{rDNA} / \mathrm{rRNA}$ : an A residue at position 906 and either an $\mathrm{A}$ or a $\mathrm{C}$ residue at position 955 (except for members of the subclasses Rubrobacteridae and Sphaerobacteridae [which show $\mathrm{U}$ residues at these positions]).

The intraclass relatedness reveals the presence of six phylogenetically distinct lineages which are consistently recovered from phylogenetic analyses (42). These lineages are described as orders (Fig. 3). The $16 \mathrm{~S}$ rDNA/rRNA signatures defining the higher taxa are based on the available $16 \mathrm{~S}$ rDNA/rRNA sequences of the type strains of type species of the genera. As certain taxa contain only one or two species, the pattern of signature nucleotides may need to be modified as new species are added to the respective genera.

Subclass Acidimicrobidae subclassis nov., Stackebrandt, Rainey, and Ward-Rainey. Acidimicrobidae (A.ci.di.mi.cro. bi'dae. M.L. n. Acidimicrobium, type genus of the subclass; -idae, ending to denote a subclass; M.L. fem. pl. n. Acidimicrobidae, the Acidimicrobium subclass). The subclass contains the type order Acidimicrobiales. The $16 \mathrm{~S}$ rDNA/rRNA signature pattern is as that of the family Acidimicrobiaceae.

Order Acidimicrobiales ordo. nov., Stackebrandt, Rainey, and Ward-Rainey. Acidomicrobiales (A.ci.di.mi.cro.bi.a'les. M.L. n. Acidimicrobium, type genus of the order; -ales, ending to denote an order; M.L. fem. pl. n. Acidimicrobiales, the Acidimicrobium order). The order contains the type family Acidimicrobiaceae. The $16 \mathrm{~S} \mathrm{rDNA} / \mathrm{rRNA}$ signature pattern is as that of the family Acidimicrobiaceae.

Family Acidimicrobiaceae fam. nov., Stackebrandt, Rainey, and Ward-Rainey. Acidimicrobiaceae (A.ci.di.mi.cro.bi.a'ce.ae. M.L. neut. n. Acidimicrobium, type genus of the family; -aceae, ending to denote a family; M.L. fem. pl. n. Acidimicrobiaceae, the Acidimicrobium family). The following pattern of $16 \mathrm{~S}$ rDNA/rRNA signature nucleotides and nucleotide pairs defines the family Acidimicrobiaceae: 291-309 (U-A), 294-303 (U-A), 408-434 (A-U), 670-736 (C-G), $722-733$ (A-C), 9551225 (C-G), 1118-1155 (C-G), 1311-1326 (A-U), and 14101490 (A-U). The family contains the type genus Acidimicrobium (24). Phylogenetic analyses have been published previously $(17,23,149)$.

Subclass Rubrobacteridae subclassis nov., Rainey, WardRainey, and Stackebrandt. Rubrobacteridae (Ru.bro.bac.te.ri' dae. M.L. masc. n. Rubrobacter, type genus of the subclass; -idae, ending to denote a subclass; M.L. fem. pl. n. Rubrobacteridae, the Rubrobacter subclass). The subclass contains the type order Rubrobacterales. The $16 \mathrm{~S} \mathrm{rDNA} / \mathrm{rRNA}$ signature pattern is as that of the family Rubrobacteraceae.

Order Rubrobacterales ordo. nov., Rainey, Ward-Rainey, and Stackebrandt. Rubrobacterales (Ru.bro.bac.te.ra'les. M.L. masc. n. Rubrobacter, type genus of the order; -ales, ending to denote an order; Rubrobacterales, the Rubrobacter order). The order contains the type family Rubrobacteraceae. The 16S rDNA/rRNA signature pattern is as that of the family Rubrobacteraceae.

Family Rubrobacteraceae fam. nov., Rainey, Ward-Rainey, and Stackebrandt. Rubrobacteraceae (Ru.bro.bac.te.ra'ce.ae.
M.L. masc. n. Rubrobacter, type genus of the family; -aceae, ending to denote a family; M.L. fem. pl. n. Rubrobacteraceae, the Rubrobacter family). The following pattern of $16 \mathrm{~S} \mathrm{rDNA} /$ rRNA signature nucleotides and nucleotide pairs defines the family: 127-234 (G-C), 291-309 (U-A), $657-749$ (G-C), 681-709 (C-G), 941-1342 (A-U), 955-1225 (U-A), 1051-1207 (C-G), 1115-1185 (C-G), 1311-1326 (A-U), and 1410-1490 (A-U). The family contains the genus Rubrobacter (157). A phylogenetic analysis has been published previously (17).

Subclass Coriobacteridae subclassis nov., Stackebrandt, Rainey, and Ward-Rainey. Coriobacteridae (Co.ri.o.bac.te.ri' dae. M.L. neut. n. Coriobacterium, type genus of the subclass; -idae, ending to denote a subclass; M.L. fem. pl. n. Coriobac teridae, the Coriobacterium subclass). The subclass contains the type order Coriobacteriales. The $16 \mathrm{~S}$ rDNA/rRNA signature pattern is as that of the family Coriobacteriaceae.

Order Coriobacteriales ordo. nov., Stackebrandt, Rainey, and Ward-Rainey. Coriobacteriales (Co.ri.o.bac.te.ri.a'les. M.L. neut. n. Coriobacterium, type genus of the order; -ales, ending to denote an order; M.L. fem. pl. n. Coriobacteriales, the Coriobacterium order). The order contains the type family Coriobacteriaceae. The $16 \mathrm{~S} \mathrm{rDNA} / \mathrm{rRNA}$ signature pattern is as that of the family Coriobacteriaceae.

Family Coriobacteriaceae fam. nov., Stackebrandt, Rainey, and Ward-Rainey. Coriobacteriaceae (Co.ri.o.bac.te.ri.a'ce.ae. M.L. neut. n. Coriobacterium, type genus of the family; -aceae, ending to denote a family; M.L. fem. pl. n. Coriobacteriaceae, the Coriobacterium family). The pattern of $16 \mathrm{~S}$ rDNA/rRNA signature nucleotides of members of the family consists of 113-314 (C-G), 294-303 (G-C), 295-302 (U-A), 670-736 (G-C), 771-808 (U-A), 772-807 (A-U), 823-877 (A-U), 941-1342 (AU), 950-1231 (U-G), 1120-1153 (G-C), 1148 (C), 1165-1171 (C-G), 1242-1295 (G-C), 1313-1324 (G-C), and 1410-1490 (A$\mathrm{U})$. The family contains the type genus Coriobacterium (61) as well as Atopobium (26). Phylogenetic analyses have been published previously $(128,146)$.

Subclass Sphaerobacteridae subclassis nov., Stackebrandt, Rainey, and Ward-Rainey. Sphaerobacteridae (Sphae.ro.bac.te. ri'dae. M.L. masc. n. Sphaerobacter, type genus of the subclass; -idae, ending to denote a subclass; M.L. fem. pl. n. Sphaerobacteridae, the Sphaerobacter subclass). The subclass contains the type order Sphaerobacterales. The 16S rDNA/rRNA signature pattern is as that of the family Sphaerobacteraceae.

Order Sphaerobacterales ordo. nov., Stackebrandt, Rainey, and Ward-Rainey. Sphaerobacterales (Sphae.ro.bac.te.ra'les M.L. masc. n. Sphaerobacter, type genus of the order; -ales, ending to denote an order; M.L. fem. pl. n. Sphaerobacterales, the Sphaerobacter order). The order contains the type family Sphaerobacteraceae. The $16 \mathrm{~S}$ rDNA/rRNA signature pattern is as that of the family Sphaerobacteraceae.

Family Sphaerobacteraceae fam. nov., Stackebrandt, Rainey, and Ward-Rainey. Sphaerobacteraceae (Sphae.ro.bac.te.ra' ce.ae. M.L. masc. n. Sphaerobacter, type genus of the family; -aceae, ending to denote a family; M.L. fem. pl. n. Sphaerobacteraceae, the Sphaerobacter family). The 16S rDNA/rRNA signature pattern for the family consists of 291-309 (U-A), 294-303 (U-A), 408-434 (A-U), 417-426 (C-G), 657-749 (G-C), 670-736 (G-C), 681-709 (C-G), 941-1342 (A-U), 955-1225 (UA), 1120-1153 (G-C), 1148 (C), and 1351-1371 (C-G). The family contains the type genus Sphaerobacter (41). A phylogenetic analysis has been published previously (41).

Subclass Actinobacteridae subclassis nov., Stackebrandt, Rainey, and Ward-Rainey. Actinobacteridae (Ac.ti.no.bac.te.ri' dae. M.L. masc. n. Actinomyces, type genus of the subclass; -idae, ending to denote a subclass; M.L. fem. pl. n. Actinobacteridae, the Actinomyces subclass). Members of Actinobacteri- 
dae can consistently be recovered as members of the same phylogenetic lineage $(42,48,133)$ (Fig. 3$)$. The subclass contains two orders, Actinomycetales and Bifidobacteriales. The type order is Actinomycetales Buchanan 1917 (13) emend. Members of the subclass contain an insertion of about 100 bases between helices 54 and 55 within domain III of the 23S rDNA (132). This insertion has not been found in members of the subclass Coriobacteridae (cf. reference 42). The pattern of $16 \mathrm{~S}$ rDNA/rRNA signatures consists of nucleotides at positions 291-309 (C-G), 294-303 (C-G), 408-434 (G-C), 670-736 (A-U), 941-1342 (G-C), 1148 (U), and 1410-1490 (G-C).

Order Actinomycetales Buchanan 1917 (13), emend. Stackebrandt, Rainey, and Ward-Rainey. Actinomycetales (Ac.ti.no. my.ce.ta'les. M.L. masc. n. Actinomyces, type genus of the order; -ales, ending to denote an order; M.L. pl. fem. n. Actinomycetales, the Actinomyces order). The $16 \mathrm{~S}$ rDNA signature pattern consists of nucleotides at positions 122-239 (A-G), 449 (A), 450-483 (G-C), 823-877 (G-C), and 1118-1155 (U-A). The order contains the suborders Actinomycineae, Corynebacterineae, Frankineae, Glycomycineae, Micrococcineae, Micromonosporineae, Propionibacterineae, Pseudonocardineae, Streptomycineae, and Streptosporangineae. The type suborder is Actinomycineae.

Suborder Actinomycineae subordo. nov., Stackebrandt, Rainey, and Ward-Rainey. Actinomycineae (Ac.ti.no.my.ci'ne.ae. M.L. masc. n. Actinomyces, type genus of the suborder; -ineae, ending to denote a suborder; M.L. fem. pl. n. Actinomycineae, the Actinomyces suborder). The $16 \mathrm{~S}$ rDNA signature pattern is as that of the type family Actinomycetaceae.

Family Actinomycetaceae Buchanan 1918 (14), emend. Stackebrandt, Rainey, and Ward-Rainey. Actinomycetaceae (Ac.ti.no. my.ce.ta'ce.ae. M.L. masc. n. Actinomyces, type genus of the family; -aceae, ending to denote a family; M.L. fem. pl. n. Actinomycetaceae, the Actinomyces family). The pattern of $16 \mathrm{~S}$ rDNA signature nucleotides consists of positions 598-640 (UG), 1059-1198 (U-A), and 1061-1195 (G-U). Genera belonging to the family are the type genus Actinomyces (63), Mobiluncus (141), and Arcanobacterium (32). Phylogenetic analyses have been published previously $(51,87,99,142)$.

Suborder Propionibacterineae subordo. nov., Rainey, WardRainey, and Stackebrandt. Propionibacterineae (Pro.pi.on.i. bac.te.ri'ne.ae. M.L. neut. n. Propionibacterium, type genus of the suborder; -ineae, ending to denote a suborder; M.L. fem. pl. n. Propionibacterineae, the Propionibacterium suborder). The pattern of $16 \mathrm{~S}$ rDNA signatures consists of nucleotides at positions 127-234 (A-U), 603-635 (A-U), 657-749 (G-C), 671735 (A-U), 986-1219 (U-A), 987-1218 (G-C), 990-1215 (U-G), and 1059-1198 (C-G). The suborder contains the type family Propionibacteriaceae and the family Nocardioidaceae.

Family Propionibacteriaceae Delwiche 1957 (40), emend. Rainey, Ward-Rainey, and Stackebrandt. Propionibacteriaceae (Pro.pi.o.ni.bac.te.ri.a'ce.ae. M.L. neut. n. Propionibacterium, type genus of the family; -aceae, ending to denote a family; M.L. fem. pl. n. Propionibacteriaceae, the Propionibacterium family). The pattern of $16 \mathrm{~S}$ rDNA signatures consists of nucleotides at positions 66-103 (A-U), 328 (U), 370-391 (C-G), 407-435 (C-G), 602-636 (A-U), 658-748 (A-U), 686 (G), 780 (A), 787 (C), 819 (G), 825-875 (A-U), and 1409-1491 (A-U). Genera included in the family are the type genus Propionibacterium (108) as well as Luteococcus (163), Microlunatus (103), and Propioniferax (187). Phylogenetic analyses have been published previously $(19,20,28,103,163,187)$.

Family Nocardioidaceae Nesterenko et al. 1985 (104), emend. Rainey, Ward-Rainey, and Stackebrandt. Nocardioidaceae (No.car.di.o.i.da'ce.ae. M.L. masc. n. Nocardioides, type genus of the family; -aceae, ending to denote a family; M.L. fem. pl. n. Nocardioidaceae, the Nocardioides family). The pattern of 16S rDNA signatures consists of nucleotides at positions 66103 (G-C), 328 (C), 370-391 (G-C), 407-435 (A-U), 602-636 (G-U), 658-748 (U-A), $686(\mathrm{U}), 780(\mathrm{G}), 787$ (A), 819 (U), 825-875 (G-C), and 1409-1491 (C-G). Genera included in the family are the type genus Nocardioides (116) and Aeromicrobium (101). Phylogenetic analyses have been published previously $(101,161)$.

Suborder Micrococcineae (Micrococceae Prevot 1961) (120), emend. Stackebrandt, Rainey, and Ward-Rainey. Micrococceae (Mi.cro.coc.ci'ne.ae. M.L. masc. n. Micrococcus, type genus of the suborder; -ineae, ending to denote a suborder; M.L. fem. pl. n. Micrococcineae, the Micrococcus suborder). The pattern of $16 \mathrm{~S}$ rDNA signatures consists of nucleotides at positions 66-103 (A-U), 70-98 (U-A), $82-87$ (G-C), 127-234 (A-U), 449 (A), 598-640 (U-G), 600-638 (U-G), 722-733 (AA), 952-1229 (C-G), 986-1219 (A-U), 987-1218 (A-U), and 1059-1198 (U-A). The type family is Micrococcaceae. Other families in the suborder include Cellulomonadaceae, Promicromonosporaceae, Dermatophilaceae, Brevibacteriaceae, Dermabacteraceae, Intrasporangiaceae, Jonesiaceae, and Microbacteriaceae.

Family Micrococcaceae Pribham 1929 (121), emend. Stackebrandt, Rainey, and Ward-Rainey. Micrococcaceae (Mi.cro. coc.ca'ce.ae. M.L. masc. n. Micrococcus, type genus of the family; -aceae, ending to denote a family; M.L. fem. pl. n. Micrococcaceae, the Micrococcus family). The pattern of $16 \mathrm{~S}$ rDNA signatures consists of nucleotides at positions 293-304 (G-U), 610 (G), 598-640 (U-U), 615-625 (G-C), 839-847 (AU), 859 (U), 1025-1036 (C-G), 1026-1035 (C-G), 1265-1270 (U-G), and $1278(\mathrm{U})$. The family contains the type genus Micrococcus (25) as well as the genera Arthrobacter (35; emended in reference 77), Kocuria (150), Nesterenkonia (150), Renibacterium (137), Rothia (52), and Stomatococcus (7). Phylogenetic analyses have been published previously $(76,150)$.

Family Cellulomonadaceae Stackebrandt and Prauser 1991 (147), emend. Stackebrandt, Rainey, and Ward-Rainey. Cellulomonadaceae (Cel.lu.lo.mo.na.da'ce.ae. M.L. fem. n. Cellulomonas, type genus of the family; -aceae, ending to denote a family; M.L. fem. pl. n. Cellulomonadaceae, the Cellulomonas family). The pattern of $16 \mathrm{~S}$ rDNA signatures consists of nucleotides at positions 30-553 (C-G), 100 (C), 183-194 (A-U), 258-268 (G-C), 610 (A), 615-625 (A-U), 630 (C), 658-748 (GA), $659-746$ (C-G), 694 (G), 747 (C), 832-854 (G-U), 859 (C), 1002-1038 (G-C), 1003-1037 (G-U), 1006-1023 (A-C), and 1256 (C). The family contains the type genus Cellulomonas (8; emended in references 24 and 153) as well as the genera Oerskovia (117; emended in reference 90 ) and Rarobacter (182). Phylogenetic analyses have been published previously (49, 129, 153).

Family Promicromonosporaceae fam. nov., Rainey, WardRainey, and Stackebrandt. Promicromonosporaceae (Pro.mi. cro.mo.no.spo.ra'ce.ae. M.L. fem. n. Promicromonospora, the type genus of the family; -aceae, ending to denote a family; M.L. fem. pl. n. Promicromonosporaceae, the Promicromonospora family). The pattern of $16 \mathrm{~S}$ rDNA signatures consists of nucleotides at positions 77-92 (G-U), 144-178 (U-G), 183-194 (C-G), 199-218 (U-U), 381 (A), 602-636 (G-U), 630 (C), 694 (G), 1002-1038 (Purine-U), 1003-1037 (G-C), 1025-1036 (UA), and 1267 (U). The family contains the type genus Promicromonospora (82). Phylogenetic analyses have been published previously $(49,129)$.

Family Dermatophilaceae Austwick 1958 (4), emend. Stackebrandt, Rainey, and Ward-Rainey. Dermatophilaceae (Der.ma.to.phi.la'ce.ae. M.L. masc. n. Dermatophilus, type genus of the family; -aceae, ending to denote a family; M.L. fem. pl. $\mathrm{n}$. 
Dermatophilaceae, the Dermatophilus family). The pattern of 16S rDNA signatures consists of nucleotides at positions 146176 (G-U), 153-168 (G-U), 502-543 (G-C), 546 (G), 580-761 (U-A), 602-636 (C-G), 615-625 (G-C), 659-746 (U-A), 825-875 (G-C), 838-848 (Pyr-Pur), and 1251 (G). The family contains the type genus Dermatophilus (170) as well as the genera Kytococcus (150) and Dermacoccus (10). Phylogenetic analyses have been published previously $(150,151)$

Family Brevibacteriaceae Breed 1953 (10), emend. Stackebrandt, Rainey, and Ward-Rainey. Brevibacteriaceae (Brev.i. bac.te.ri.a'ce.ae. M.L. neut. n. Brevibacterium, type genus of the family; -aceae, ending to denote a family; M.L. fem. pl. $\mathbf{n}$. Brevibacteriaceae, the Brevibacterium family). The pattern of 16S rDNA signatures consists of nucleotides at positions 41 401 (U-A), 69-99 (C-U), 142-221 (U-A), 144-178 (U-G), $407-$ 435 (C-G), 586-755 (U-A), 591-648 (G-U), 612-628 (G-C), 616-624 (C-G), 631 (G), 660-745 (A-U), 670-736 (U-A), 896903 (U-G), 1011-1018 (U-A), 1012-1017 (G-C), 1244-1293 (UA), 1254-1283 (A-C), 1256 (A), 1257 (G), 1262 (A), 1263-1272 (C-G), 1310-1327 (U-A), and 1442-1460 (U-G). The family contains the type genus Brevibacterium (10; emended in reference 31). Phylogenetic analyses have been published previously $(16,127)$.

Family Dermabacteraceae fam. nov., Stackebrandt, Rainey, and Ward-Rainey. Dermabacteraceae (Der.ma.bac.te.ra'ce.ae. M.L. masc. n. Dermabacter, type genus of the family; -aceae, ending to denote a family; M.L. fem. pl. n. Dermabacteraceae, the Dermabacter family). The pattern of 16S rDNA signatures consists of nucleotides at positions 153-168 (C-G), 248-276 (U-G), 258-268 (A-U), 280 (U), 407-435 (G-U), 580-761 (UA), 586-755 (U-A), 589-650 (C-G), 602-636 (C-G), 615-625 (A-U), 838-848 (Pur-Pyr), and 1189 (C). The family contains the type genus Dermabacter (69) as well as the genus Brachybacterium (27). Phylogenetic analyses have been published previously $(16,139)$.

Family Intrasporangiaceae fam. nov. Rainey, Ward-Rainey, and Stackebrandt. Intrasporangiaceae (In.tra.spo.ran.gi.a'ce. ae. M.L. neut. n. Intrasporangium, type genus of the family; -aceae, ending to denote a family; M.L. fem. pl. n. Intrasporangiaceae, the Intrasporangium family). The pattern of $16 \mathrm{~S}$ rDNA signatures consists of nucleotides at positions 30-553 (C-G), $69-99$ (G-U), 140-223 (G-C), 157-164 (G-C), 258-268 (A-U), 630 (C), 658-748 (G-U), 659-746 (U-A), 660-745 (GC), 694 (G), 838-848 (C-G), 839-847 (U-A), 859 (C), 1003-1037 (G-C), 1007-1022 (C-G), 1133-1141 (A-U), and 1134-1140 (C$\mathrm{G})$. The family contains the type genus Intrasporangium (71) as well as the genera Sanguibacter (47) and Terrabacter (29). Phylogenetic analyses have been published previously $(29,47)$.

Family Jonesiaceae fam. nov., Stackebrandt, Rainey, and Ward-Rainey. Jonesiaceae (Jone.si.a'ce.ae. M.L. fem. n. Jonesia, type genus of the family; -aceae, ending to denote a family; M.L. fem. pl. n. Jonesiaceae, the Jonesia family). The pattern of $16 \mathrm{~S}$ rDNA signatures consists of nucleotides at positions 153168 (C-G), 280 (U), 379-384 (G-C), 407-435 (G-U), 445-489 (A-U), 589-650 (U-G), 602-636 (U-G), 615-625 (A-U), 668738 (U-A), 838-848 (Pur-Pyr), and 1189 (C). The family contains the type genus Jonesia (130). Phylogenetic analyses have been published previously $(49,129)$.

Family Microbacteriaceae Park et al. 1993 (113), emend. Rainey, Ward-Rainey, and Stackebrandt. Microbacteriaceae (Mi.cro.bac.te.ri.a'ce.ae. M.L. masc. n. Microbacterium, type genus of the family; -aceae, ending to denote a family; M.L. fem. pl. n. Microbacteriaceae, the Microbacterium family). The pattern of $16 \mathrm{~S}$ rDNA signatures consists of nucleotides at positions 45-396 (U-A), 144-178 (C-G), 258-268 (A-U), 497 (A), 615-625 (A-U), 694 (G), 771-808 (G-C), 839-847 (G-U),
1256 (C), 1310-1327 (A-U), and 1414-1486 (U-A). The family contains the type genus Microbacterium (109) as well as the genera Agrococcus (58), Agromyces (54), Aureobacterium (30), Clavibacter (39), Curtobacterium (181), and Rathayibacter (189). Phylogenetic analyses have been published previously $(58,122,158,159)$.

Suborder Corynebacterineae subordo. nov., Stackebrandt, Rainey, and Ward-Rainey. Corynebacterineae (Co.ry.ne.bac.te. ri'ne.ae. M.L. masc. n. Corynebacterium, type genus of the suborder; -ineae, ending to denote a suborder; M.L. fem. pl. n. Corynebacterineae, the Corynebacterium suborder). The pattern of 16S rDNA signatures consists of nucleotides at positions 127-234 (G-C), 131-231 (U-Pur), 502-543 (A-U), 658-748 (AA), 564 (C), 600-638 (G-C), 601-637 (U-G), 660-745 (U-A), $671-735$ (C-G), 819 (G), 952-1229 (U-A), 986-1219 (U-A), 1116-1184 (U-G), and 1414-1486 (U-G). The suborder contains the type family Corynebacteriaceae as well as the families Dietziaceae, Gordoniaceae, Mycobacteriaceae, Nocardiaceae, and Tsukamurellaceae.

Family Corynebacteriaceae Lehmann and Neumann 1907 (95), emend. Stackebrandt, Rainey, and Ward-Rainey. Corynebacteriaceae (Co.ry.ne.bac.te.ri.a'ce.ae. M.L. neut. n. Corynebacterium, type genus of the family; -aceae, ending to denote a family; M.L. fem. pl. n. Corynebacteriaceae, the Corynebacterium family). The pattern of $16 \mathrm{~S}$ rDNA signatures consists of nucleotides at positions 293-304 (G-U), 307 (A), 316-337 (UG), $468(\mathrm{U}), 508(\mathrm{U}), 586-755(\mathrm{U}-\mathrm{G}), 631(\mathrm{G}), 661-744(\mathrm{G}-\mathrm{C})$, 662-743 (U-G), 771-808 (A-U), 824-876 (C-G), 825-875 (G-C) 837-849 (G-U), 843 (C), and 1059-1198 (U-A). The family contains the type genus Corynebacterium (94) as well as the genus Turicella (50). Phylogenetic analyses have been published previously $(50,114,135)$.

Family Mycobacteriaceae Chester 1897 (21), emend. Stackebrandt, Rainey, and Ward-Rainey. Mycobacteriaceae (My.co. bac.te.ri.a'ce.ae. M.L. neut. n. Mycobacterium, type genus of the family; -aceae, ending to denote a family; M.L. fem. pl. $\mathrm{n}$. Mycobacteriaceae, the Mycobacterium family). The pattern of 16S rDNA signatures consists of nucleotides at positions 70-98 (A-U), 293-304 (G-U), 307 (C), 328 (U), 614-626 (A-U), 631 (G), 661-744 (G-C), 824-876 (U-A), 825-875 (A-U), 843 (C), and 1122-1151 (A-U). The family contains the type genus $M y$ cobacterium (94). Phylogenetic analyses have been published previously $(115,131)$.

Family Nocardiaceae Castellani and Chalmers 1919 (18), emend. Rainey, Ward-Rainey, and Stackebrandt. Nocardiaceae (No.car.di.a'ce.ae. M.L. fem. n. Nocardia type genus of the family; -aceae, ending to denote a family; M.L. fem. pl. $n$ Nocardiaceae, the Nocardia family). The pattern of $16 \mathrm{~S}$ rDNA signatures consists of nucleotides at positions $70-98$ (U-A) 139-224 (G-C), 843 (C), 1008-1021 (C-G), 1189 (C), 1244-1293 (C-G), and 1308-1329 (C-G). The family contains the type genus Nocardia (169) as well as the genus Rhodococcus (190). Phylogenetic analyses have been published previously $(22,124$, 134).

Family Gordoniaceae fam. nov., Rainey, Ward-Rainey, and Stackebrandt. Gordoniaceae (Gor.do.ni.a'ce.ae. M.L. fem. n. Gordonia, type genus of the family; -aceae, ending to denote a family; M.L. fem. pl. n. Gordoniaceae, the Gordonia family). The pattern of $16 \mathrm{~S}$ rDNA signatures consists of nucleotides at positions 70-98 (A-U), 293-304 (A-U), 307 (U), 661-744 (AU), 824-876 (U-A), 825-875 (A-U), 843 (U), 1002-1038 (A-U), 1007-1022 (C-G), 1122-1151 (G-C), and 1124-1149 (A-U). The family contains the type genus Gordonia (154). Corrigendum: The name Gordonia, not Gordona, is proposed as the correct etymology. Phylogenetic analyses have been published previously $(6,124,134)$. 
Family Tsukamurellaceae fam. nov., Rainey, Ward-Rainey, and Stackebrandt. Tsukamurellaceae (Tsu.ka.mu.rel.la'ce.ae. M.L. fem. n. Tsukamurella, type genus of the family; -aceae, ending to denote a family; M.L. fem. pl. n. Tsukamurellaceae, the Tsukamurella family). The pattern of 16S rDNA signatures consists of nucleotides at positions 70-98 (U-A), 293-304 (GU); 307 (C), 631 (C), 661-744 (G-C), 824-876 (U-A), 825-875 (A-U), 843 (C), 1007-1022 (G-U), and 1122-1151 (A-U). The family contains the type genus Tsukamurella (33). Phylogenetic analyses have been published previously $(33,124,183)$.

Family Dietziaceae fam. nov., Rainey, Ward-Rainey, and Stackebrandt. Dietziaceae (Diet.zi.a'ce.ae. M.L. fem. n. Diet$z i a$, type genus of the family; -aceae, ending to denote a family. M.L. fem. pl. n. Dietziaceae, the Dietzia family). The pattern of 16S rDNA signatures consists of nucleotides at positions 70-98 (U-A), 293-304 (G-U), 307 (U), 418-425 (U-A), 508 (U), 614626 (U-G), 631 (G), 661-744 (A-U), 771-808 (A-U), 824-876 (C-G), 825-875 (G-C), 843 (C), 1049-1198 (U-A), and 11221151 (A-U). The family contains the type genus Dietzia (125). A phylogenetic analysis has been published previously (124).

Suborder Pseudonocardineae subordo. nov., Stackebrandt, Rainey, and Ward-Rainey. Pseudonocardineae (Pseu.do.no. car'di.ne.ae. M.L. fem. n. Pseudonocardia, the type genus of the suborder; -ineae, ending to denote a suborder; M.L. fem. pl. n. Pseudonocardineae, the Pseudonocardia suborder). The pattern of $16 \mathrm{~S}$ rDNA signatures is as that for the family. The type family is Pseudonocardiaceae.

Family Pseudonocardiaceae Warwick et al. $1994(175)$ emend. Stackebrandt, Rainey, and Ward-Rainey. Pseudonocardiaceae (Pseu.do.no.car.di.a'ce.ae. M.L. fem. n. Pseudonocardia, type genus of the family; -aceae, ending to denote a family; M.L. fem. pl. n. Pseudonocardiaceae, the Pseudonocardia family). The pattern of $16 \mathrm{~S}$ rDNA signatures consists of nucleotides at positions 127-234 (G-C), 183-194 (G-U), 502543 (A-U), 603-635 (C-G), 610 (A), 747 (A), 952-1229 (U-A), 986-1219 (U-A), 987-1218 (G-C), 1001-1039 (Pyr-G), and 1308-1329 (C-G). Comment: Although in phylogenetic terms this family is rather broad, it is currently not possible to subdivide the family due to the lack of an unambiguous pattern of signature nucleotides. The family contains the type genus Pseudonocardia (66) as well as the genera Actinopolyspora (55), Actinosynnema (65), Amycolatopsis (92), Kibdelosporangium (140), Kutzneria (152), Lentzea (184), Saccharomonospora (106), Saccharopolyspora (86), Saccharothrix (84), Streptoalloteichus (168), and Thermocrispum (79). Phylogenetic analyses have been published previously $(9,43,74,79,175$, 184).

Suborder Streptomycineae subordo. nov., Rainey, Ward-Rainey, and Stackebrandt. Streptomycineae (Strep.to.my.ci'ne.ae. M.L. masc. n. Streptomyces, type genus of the suborder; -ineae, ending to denote a suborder; M.L. fem. pl. n. Streptomycineae, the Streptomyces suborder). The pattern of signature nucleotides of $16 \mathrm{~S}$ rDNA is as that of the type family Streptomycetaceae.

Family Streptomycetaceae Waksman and Henrici 1943 (171), emend. Rainey, Ward-Rainey, and Stackebrandt. Streptomycetaceae (Strep.to.my.ce.ta'ce.ae. M.L. masc. n. Streptomyces, type genus of the family; -aceae, ending to denote a family; M.L. fem. pl. n. Streptomycetaceae, the Streptomyces family). The family is emended to exclude the genus Sporichthya. The pattern of 16S rDNA signature nucleotides consists of $71(\mathrm{G})$ 80-89 (G-C), 81-88 (C-G), 82-87 (U-G), 127-234 (G-C), 209 (C), $210(\mathrm{C}), 211(\mathrm{G}), 610(\mathrm{G}), 671-735(\mathrm{U}-\mathrm{A}), 819(\mathrm{G}), 837$ 849 (C-G), 950-1231 (U-G), 955-1225 (C-G), 965 (C), 12541283 (A-U), and 1409-1491 (C-G). The family contains the type genus Streptomyces (171; emended in references 176 and
178). Phylogenetic analyses have been published previously $(73,155,160,176,178)$.

Suborder Streptosporangineae subordo. nov., Ward-Rainey, Rainey, and Stackebrandt. Streptosporangineae (Strep.to.spo. ran.gi'ne.ae. M.L. neut. n. Streptosporangium, type genus of the suborder; -ineae, ending to denote a suborder; M.L. fem. pl. n. Streptosporangineae, the Streptosporangium suborder). The pattern of $16 \mathrm{~S}$ rDNA signatures consists of nucleotides at positions 127-234 (A-U), 657-749 (G-Pyr), and 955-1225 (C-G). The type family is Streptosporangiaceae.

Family Streptosporangiaceae Goodfellow et al. 1990 (56) (validation list no. 34), emend. Ward-Rainey, Rainey, and Stackebrandt. Streptosporangiaceae (Strep.to.spo.ran.gi.a'ce.ae. M.L. neut. n. Streptosporangium, type genus of the family; -aceae, ending to denote a family; M.L. fem. pl. n. Streptosporangiaceae, the Streptosporangium family). The pattern of $16 \mathrm{~S}$ rDNA signatures consists of nucleotides at positions 440-494 (C-G), 445-489 (G-C), 501-544 (C-G), 502-543 (G-C), no extra base between positions 453 and 479, 586-755 (U-G), 613-627 (PyrPur), 681-709 (U-A), 1116-1184 (U-G), 1137 (U), 1355-1367 (A-U), 1436-1465 (GC), and 1422-1478 (G-U). The family contains the type genus Streptosporangium (37) as well as the genera Herbidospora (83), Microbispora (105), Microtetraspora (167), Planobispora (164), and Planomonospora (166). Phylogenetic analyses have been published previously $(172,174)$.

Family Nocardiopsaceae Rainey et al. 1996 (127), emend. Rainey, Ward-Rainey, and Stackebrandt. Nocardiopsaceae (No.car.di.op.sa'ce.ae. M.L. fem. n. Nocardiopsis, type genus of the family; -aceae, ending to denote a family; M.L. fem. pl. n. Nocardiopsaceae, the Nocardiopsis family). The pattern of $16 \mathrm{~S}$ rDNA signatures consists of nucleotides at positions 440-494 (U-G), 442-492 (C-G), 445-489 (C-G), four extra bases between positions 453 and 479, 501-544 (G-C), 502-543 (A-U), 586-755 (C-G), 603-635 (U-A), 613-627 (C-G), 658-748 (U-A), 671-735 (C-G), 681-709 (U-A), 1003-1037 (U-G), 1116-1184 (C-G), 1137 (A), 1355-1367 (G-C), 1422-1478 (G-U), and 1435-1466 (A-U). The family contains the type genus Nocardiopsis (100). A phylogenetic analysis has been published previously (127).

Family Thermomonosporaceae fam. nov., Rainey, Ward-Rainey, and Stackebrandt. Thermomonosporaceae (Ther.mo.mo.no. spo.ra'ce.ae. M.L. fem. n. Thermomonospora, type genus of the family; -aceae, ending to denote a family; M.L. fem. pl. n. Thermomonosporaceae, the Thermomonospora family). The pattern of $16 \mathrm{~S}$ rDNA signatures consists of nucleotides at positions $440-494$ (C-G), 442-492 (G-C), four to seven extra bases between position 453 and 479, 501-544 (C-G), 502-543 (G-C), 586-755 (C-G), 613-627 (C-G), 658-748 (C-U), 681-709 (C-G), 1003-1037 (A-G), 1116-1184 (C-G), 1355-1367 (A-U), 1422-1478 (G-C), and 1435-1466 (G-C). The family contains the type genus Thermomonospora (66) as well as the genera Actinomadura (89) and Spirillospora (38). Phylogenetic analyses have been published previously $(127,172)$.

Suborder Micromonosporineae subordo. nov., Stackebrandt, Rainey, and Ward-Rainey. Micromonosporineae (Mi.cro.mo. no.spo.ri'ne.ae. M.L. fem. n. Micromonospora, type genus of the suborder; -ineae, ending to denote a suborder; M.L. fem. pl. n. Micromonosporineae, the Micromonospora suborder) The pattern of 16S rDNA signature nucleotides is as indicated for the family. The suborder contains the type family $M i$ cromonosporaceae.

Family Micromonosporaceae Krassilnikov 1938 (80), emend. Koch et al. 1996 (78), emend. Stackebrandt, Rainey, and Ward-Rainey. Micromonosporaceae (Mi.cro.mo.no.spo.ra'ce.ae. M.L. fem. n. Micromonospora, type genus of the family; -aceae, ending to denote a family; M.L. fem. pl. n. Micromonospora- 
ceae, the Micromonospora family). The pattern of $16 \mathrm{~S}$ rDNA signatures consists of nucleotides at positions $66-103$ (G-C), 127-234 (A-U), 153-168 (C-G), 502-543 (G-C), 589-650 (C-G), 747 (A), 811 (U), 840-846 (C-G), 952-1229 (C-G), 1116-1184 (C-G), and 1133-1141 (G-C). The family contains the type genus Micromonospora (111) as well as the genera Actinoplanes (36; emended in reference 145), Catellatospora (3), Couchioplanes (162), Catenuloplanes (185), Dactylosporangium (165), and Pilimelia (72). Phylogenetic analyses have been published previously $(75,78)$.

Suborder Frankineae subordo. nov., Stackebrandt, Rainey, and Ward-Rainey. Frankineae (Frank.i'ne.ae. M.L. fem. n. Frankia, type genus of the suborder; -ineae, ending to denote a suborder; M.L. fem. pl. n. Frankineae, the Frankia suborder). The pattern of 16S rDNA signatures consists of nucleotides at positions 82-87 (C-G), 127-234 (G-C), 141-222 (G-C), 371-390 (G-C), 502-543 (A-U), and 1003-1037 (G-G). The suborder contains the type family Frankiaceae as well as the families Acidothermaceae, Microsphaeraceae, Geodermatophilaceae, and Sporichthyaceae. Phylogenetic analyses have been published previously $(44,62,107,123,126)$.

Family Frankiaceae Becking 1970 (5), emend. Hahn et al. 1989 (62), emend. Normand et al. 1996 (107), emend. Stackebrandt, Rainey, and Ward-Rainey. Frankiaceae (Frank.i.a' ce.ae. M.L. fem. n. Frankia, type genus of the family; -aceae, ending to denote a family; M.L. fem. pl. n. Frankiaceae, the Frankia family). The $16 \mathrm{~S}$ rDNA signature nucleotide pattern consists of 139-224 (G-C), 148-174 (A-G), 155-166 (U-G), 839847 (A-G), 987-1218 (G-C), 1059-1198 (C-G), and 1308-1329 (C-G). The family contains the type genus Frankia (12). Phylogenetic analyses have been published previously $(62,107)$.

Family Geodermatophilaceae Normand et al. 1996 (107), emend. Stackebrandt, Rainey, and Ward-Rainey. Geodermatophilaceae (Ge.o.der.ma.to.phi.la'ce.ae. M.L. masc. n. Geodermatophilus, type genus of the family; -aceae, ending to denote a family; M.L. fem. pl. n. Geodermatophilaceae, the Geodermatophilus family. The pattern of $16 \mathrm{~S}$ rDNA signatures consists of nucleotides at positions 139-224 (C-G), 157-164 (A-U), 158-163 (A-U), 186-191 (C-G), 263 (G), 293-304 (G-U), 9861219 (U-A), 987-1218 (A-U), 1059-1198 (U-A), and 1308-1329 (U-A). The family contains the type genus Geodermatophilus (98) as well as the genus Blastococcus (2). Phylogenetic analyses have been published previously $(44,107)$.

Family Microsphaeraceae fam. nov., Rainey, Ward-Rainey, and Stackebrandt. Microsphaeraceae (Mi.cro.sphae.ra'ce.ae. M.L. fem. n. Microsphaera, type genus of the family; -aceae, ending to denote a family; M.L. fem. pl. n. Microsphaeraceae, the Microsphaera family). The pattern of 16S rDNA signatures consists of nucleotides at positions 139-224 (C-G), 157-164 (G-C), 186-191 (C-G), 839-847 (U-A), 987-1218 (A-U), 10591198 (U-A), and 1308-1329 (U-A). The family contains the type genus Microsphaera (188). A phylogenetic analysis has been published previously (188).

Family Sporichthyaceae fam. nov., Rainey, Ward-Rainey, and Stackebrandt. Sporichthyaceae (Spo.rich.thy.a'ce.ae. M.L. fem. $\mathrm{n}$. Sporichthya, type genus of the family; -aceae, ending to denote a family; M.L. fem. pl. n. Sporichthyaceae, the Sporichthya family). The pattern of $16 \mathrm{~S}$ rDNA signatures consists of nucleotides at positions 139-224 (U-A), 186-191 (G-C), 600638 (C-G), 839-847 (U-A), 987-1218 (A-U), 1059-1198 (U-A), and 1308-1329 (U-A). The family contains the type genus Sporichthya (91). A phylogenetic analysis has been published previously (126).

Family Acidothermaceae fam. nov., Rainey, Ward-Rainey, and Stackebrandt. Acidothermaceae (A.ci.do.ther.ma'ce.ae. M.L. masc. n. Acidothermus, type genus of the family; -aceae, ending to denote a family; M.L. fem. pl. n. Acidothermaceae, the Acidothermus family). The pattern of 16S rDNA signatures consists of nucleotides at positions 139-224 (C-G), 186-191 (G-C), 839-847 (A-U), 987-1218 (G-C), 1059-1198 (C-G), and 1308-1329 (C-G). The family contains the type genus Acidothermus (102). A phylogenetic analysis has been published previously (123).

Suborder Glycomycineae subordo. nov., Rainey, WardRainey, and Stackebrandt. Glycomycineae (Gly.co.my.ci.ne'ae. M.L. masc. n. Glycomyces, type genus of the suborder; -ineae, ending to denote a suborder; M.L. fem. pl. n. Glycomycineae, the Glycomyces suborder). The pattern of signature nucleotides of $16 \mathrm{~S}$ rDNA is as that of the type family Glycomycetaceae.

Family Glycomycetaceae fam. nov., Rainey, Ward-Rainey, and Stackebrandt. Glycomycetaceae (Gly.co.my.ce.ta'ce.ae M.L. masc. n. Glycomyces, type genus of the family; -aceae, ending to denote a family; M.L. fem. pl. n. Glycomycetaceae, the Glycomyces family). The $16 \mathrm{~S}$ rDNA pattern of $16 \mathrm{~S}$ rDNA signature nucleotides contains 70-98 (A-U), 127-234 (G-Pyr), 140-223 (A-U), 229 (G), 366 (U), 415 (C), 449 (C), 534 (G), 681-709 (A-U), 825-875 (G-C), 999-1041 (C-G), 1059-1198 (C-G), 1064-1192 (G-G), 1117-1183 (A-U), and 1309-1328 (C$\mathrm{G})$. The family contains the type genus Glycomyces (85). The phylogenetic position is shown in Fig. 3.

Order Bifidobacteriales ordo. nov., Stackebrandt, Rainey, and Ward-Rainey. Bifidobacteriales (Bi.fi.do.bac.te.ri.a'les. M.L. neut. n. Bifidobacterium, type genus of the order; -ales, ending to denote an order; M.L. fem. pl. n. Bifidobacteriales, the Bifidobacterium order). The type family of the order is Bifidobacteriaceae. The $16 \mathrm{~S}$ rDNA nucleotide signature is as that of the family.

Family Bifidobacteriaceae fam. nov., Stackebrandt, Rainey, and Ward-Rainey. Bifidobacteriaceae (Bi.fi.do.bac.te.ri.a'ce.ae. M.L. neut. n. Bifidobacterium, type genus of the family; -aceae, ending to denote a family; M.L. fem. pl. n. Bifidobacteriaceae, the Bifidobacterium family). The pattern of $16 \mathrm{~S}$ rDNA signatures consists of nucleotides at positions 122-239 (G-U), 128 233 (C-G), 450-483 (C-G), 602-636 (G-C), 681-709 (C-G), 688-699 (A-U), 823-877 (A-U), 1118-1155 (C-G), and 1311-1326 (A-U). The family contains the type genus Bifidobacterium (110) as well as Gardnerella (57). A phylogenetic structure of the family has been published previously $(88,99)$.

\section{ACKNOWLEDGMENT}

We are indebted to Hans G. Trüper for his advice in the nomenclatural aspect of this work.

\section{REFERENCES}

1. Agre, N. S., and L. N. Guzeva. 1975. New actinomycetes genus Excellospora gen. nov. Mikrobiologiya 44:518-523.

2. Ahrens, R., and G. Moll. 1970. Ein neues knospendes Bakterium aus der Ostsee. Arch. Mikrobiol. 70:243-265.

3. Asano, K., and I. Kawamoto. 1986. Catellatospora, a new genus of Actinomycetales. Int. J. Syst. Bacteriol. 36:512-517.

4. Austwick, P. K. C. 1958. Cutaneous streptothrichosis mycotic dermatitis and strawberry foot rot and the genus Dermatophilus. Van Saceghem Vet. Rev. Annot. 4:33-48.

5. Becking, J. H. 1970. Frankiaceae fam. nov. Actinomycetales with one new combination and six new species of the genus Frankia Brunchorst 1887, 174 Int. J. Syst. Bacteriol. 20:201-220.

6. Bendinger, B., F. A. Rainey, R. M. Kroppenstedt, M. Moormann, and S. Klatte. 1995. Gordona hydrophobica sp. nov., isolated from biofilters for waste gas treatment. Int. J. Syst. Bacteriol. 45:544-548.

7. Bergan, T., and M. Kocur. 1982. Stomatococcus mucilaginosus gen. nov. sp. nov. ep. rev., a member of the family Micrococcaeae. Int. J. Syst. Bacteriol 32:374-377.

8. Bergey, D. H., F. C. Harrison, R. S. Breed, B. W. Hammer, and F. M. Huntoon. 1923. Bergey's manual of determinative bacteriology, 1st ed. The Williams and Wilkins Co., Baltimore, Md. 
9. Bowen, T., E. Stackebrandt, M. Dorsch, and T. M. Embley. 1989. Transfer of the genera Kibdelosporangium, Saccharothrix and Amycolata into the family Pseudonocardiaceae. J. Gen. Microbiol. 135:2529-2536.

10. Breed, R. S. 1953 . The families developed from Bacteriaceae Cohn with a description of the family Brevibacteriaceae. VI Congr. Int. Microbiol. Roma 1:10-15.

11. Brosius, J., M. L. Palmer, J. P. Kennedy, and H. P. Noller. 1978. Complete nucleotide sequence of a 16S ribosomal RNA gene from Escherichia coli. Proc. Natl. Acad. Sci. USA 75:4801-4805.

12. Brunchorst, J. 1886. Über einige Wurzelanschwellungen besonders diejenigen von Alnus und den Elaeagnaceen. Bot. Inst. Tübingen 2:151-177.

13. Buchanan, R. E. 1917. Studies in the nomenclature and classification of the bacteria. II. The primary subdivisions of the schizomycetes. J. Bacteriol. 2:155-164.

14. Buchanan, R. E. 1918. Studies in the nomenclature and classification of the bacteria. VIII. The subgroups and genera of the Actinomycetales. J. Bacteriol. 3:403-406

15. Burggraf, S., G. J. Olsen, K. O. Stetter, and C. R. Woese. 1992. A phylogenetic analysis of Aquifex pyrophilus. Syst. Appl. Microbiol. 15:352-356.

16. Cai, J., and M. D. Collins. 1994. Phylogenetic analysis of species of the meso-diaminopimelic acid-containing genera Brevibacterium and Dermabacter. Int. J. Syst. Bacteriol. 44:583-585.

17. Carreto, L., E. Moore, M. F. Nobre, R. Wait, P. W. Riley, R. J. Sharp, and M. S. da Costa. 1996. Rubrobacter xylanophilus sp. nov., a new thermophilic species isolated from a thermally polluted effluent. Int. J. Syst. Bacteriol. 46:460-465.

18. Castellani, A., and A. J. Chalmers. 1919. Manual of tropical medicine, 3rd ed. Williams, Wood and Co., New York, N.Y

19. Charfreitag, O., and E. Stackebrandt. 1989. Intra- and intergeneric relationships of the genus Propionibacterium. J. Gen. Microbiol. 135:2065-2070.

20. Charfreitag, O., M. D. Collins, and E. Stackebrandt. 1988. Phylogenetic and chemotaxonomic evidence for the reclassification of Arachnia propionica as Propionibacterium propionicus comb. nov. Int. J. Syst. Bacteriol. 38:354-357.

21. Chester, F. D. 1897. Report of the mycologist; bacteriological work. Del. Agr. Exp. Stn. Bull. 9:38-145.

22. Chun, J., and M. Goodfellow. 1995. A phylogenetic analysis of the genus Nocardia with 16S rRNA gene sequences. Int. J. Syst. Bacteriol. 45:240-245.

23. Clark, D. A., and P. R. Norris. 1996. Acidimicrobium ferrooxidans gen. nov. sp. nov. mixed-culture ferrous iron oxidation with Sulfobacillus species. Microbiology (Reading) 142:785-790.

24. Clark, F. E. 1952. The generic classification of the soil bacteria. Bull. Bact. Nom. Tax. 2:45-56.

25. Cohn, F. 1872. Untersuchungen über Bakterien. Beitr. Biol. Pflanz. 1:127224.

26. Collins, M. D., and S. Wallbanks. 1992. Comparative sequence analysis of the 16S rRNA genes of Lactobacillus minutus, Lactobacillus rimae and Streptococcus parvulus. Proposal for the creation of a new genus Atopobium. FEMS Microbiol. Lett. 95:235-240.

27. Collins, M. D., J. Brown, and D. Jones. 1988. Brachybacterium faecium gen. nov., sp. nov., a coryneform bacterium from poultry deep litter. Int. J. Syst. Bacteriol. 38:45-48.

28. Collins, M. D., S. Cockcroft, and S. Wallbanks. 1994. Phylogenetic analysis of a new LL-diaminopimelic acid-containing coryneform bacterium from herbage, Nocardioides plantarum sp. nov. Int. J. Syst. Bacteriol. 44:523-526.

29. Collins, M. D., M. Dorsch, and E. Stackebrandt. 1989. Transfer of Pimelobacter tumescens to Terrabacter gen. nov. as Terrabacter tumescens comb. nov. and of Pimelobacter jensenii to Nocardioides as Nocardioides jensenii comb. nov. Int. J. Syst. Bacteriol. 39:1-6.

30. Collins, M. D., D. Jones, R. M. Keddie, R. M. Kroppenstedt, and K. H. Schleifer. 1983. Classification of some coryneform bacteria in a new genus Aureobacterium. Syst. Appl. Microbiol. 4:236-252.

31. Collins, M. D. D. Jones, R. M. Keddie, and P. A. H. Sneath. 1980. Reclassification of Chromobacterium iodinum Davis in a redefined genus Brevibacterium Breed as Brevibacterium iodinum nom. rev.; comb. nov. J. Gen. Microbiol. 120:1-10.

32. Collins, M. D. D. Jones, and G. M. Schofield. 1982. Reclassification of "Corynebacterium haemolyticum" MacLean, Liebow and Rosenberg in the genus Arcanobacterium gen. nov. as Arcanobacterium haemolyticum nom. rev., comb. nov. J. Gen. Microbiol. 128:1279-1281

33. Collins, M. D., J. Smida, M. Dorsch, and E. Stackebrandt. 1988. Tsuka murella gen. nov., harboring Connebacterium paurometabolum and Rhodococcus aurantiacus. Int. J. Syst. Bacteriol. 38:385-391.

34. Colwell, R. R. 1970. Polyphasic taxonomy of bacteria, p. 421-436. In H. Iizuka and T. Hasegawa (ed.), Proceedings of the International Conference on Culture Collections. Tokyo University Press, Tokyo, Japan.

35. Conn, H. J., and I. Dimmick. 1947. Soil bacteria similar in morphology to Mycobacterium and Corynebacterium. J. Bacteriol. 54:291-303.

36. Couch, J. N. 1950. Actinoplanes a new genus of the Actinomycetales. J. Elisha Mitchell Sci. Soc. 66:87-92.

37. Couch, J. N. 1955. A new genus and family of the Actinomycetales, with a revision of the genus Actinoplanes. J. Elisha Mitchell Sci. Soc. 71:148-155.

38. Couch, J. N. 1963. Some new genera and species of the Actinoplanaceae. J. Elisha Mitchell Sci. Soc. 79:53-70.

39. Davis, M. J., A. G. Gillaspie, Jr., A. K. Vidaver, and R. W. Harris. 1984. Clavibacter: a new genus containing some phytopathogenic coryneform bacteria, including Clavibacter xyli subsp. xyli sp. nov, subsp. nov. and Clavibacter xyli subsp. cynodontis subsp. nov., pathogens that cause ratoon stunting disease of sugarcane and Bermudagrass stunting disease. Int. J. Syst. Bacteriol. 34:107-117.

40. Delwiche, E. A. 1957. Family XI Propionibacteriaceae, p. 569. In R. S. Breed, E. G. D. Murray, and N. R. Smith (ed.), Bergey's manual of determinative bacteriology, 7th ed. The Williams and Wilkins Co., Baltimore, Md.

41. Demharter, W., R. Hensel, J. Smida, and E. Stackebrandt. 1989. Sphaerobacter thermophilus gen. nov. spec. nov, a deeply rooting member of the actinomycetes subdivision isolated from thermophilically treated sewage sludge. Syst. Appl. Microbiol. 11:261-266.

42. Embley, T. M., and E. Stackebrandt. 1994. The molecular phylogeny and systematics of the actinomycetes. Annu. Rev. Microbiol. 48:257-289.

43. Embley, T. M., J. Smida, and E. Stackebrandt. 1988. The phylogeny of mycolate-less wall chemotype IV actinomycetes and description of Pseudonocardiaceae family nov. Syst. Appl. Microbiol. 11:44-52.

44. Eppard, M., W. E. Krumbein, C. Koch, E. Rhiel, J. T. Staley, and E. Stackebrandt. 1996. Morphological, physiological, and molecular characterization of actinomycetes isolated from dry soil, rocks, and monument surfaces. Arch. Microbiol. 166:12-22.

45. Felsenstein, J. 1985 . Confidence limits on phylogenies. An approach using the bootstrap. Evolution 39:783-789.

46. Felsenstein, J. 1993. PHYLIP phylogenetic inference package version 3.5.1. Department of Genetics, University of Washington, Seattle.

47. Fernandez-Garayzabal, J. F., L. Dominguez, C. Pascual, D. Jones, and M. D. Collins. 1995. Phenotypic and phylogenetic characterization of some unknown coryneform bacteria isolated from bovine blood and milk. Description of Sanguibacter gen. nov. Lett. Appl. Microbiol. 20:69-75.

48. Fox, G. E., and E. Stackebrandt. 1987. The application of 16S rRNA cataloguing and 5S rRNA sequencing in microbial systematics. Methods Microbiol. 19:405-458.

49. Funke, G., C. P. Ramos, and M. D. Collins. 1995. Identification of some clinical strains of CDC coryneform group A-3 and A-4 bacteria as Cellulomonas species and proposal of Cellulomonas hominis sp. nov. for some group A-3 strains. J. Clin. Microbiol. 33:2091-2097.

50. Funke, G., S. Stubbs, M. Altwegg, A. Carlotti, and M. D. Collins. 1994 Turicella otitidis gen nov, $\mathrm{sp}$ nov, a coryneform bacterium isolated from patients with otitis media. Int. J. Syst. Bacteriol. 44:270-273.

51. Funke, G., S. Stubbs, A. von Graevenitz, and M. D. Collins. 1994. Assignment of human-derived CDC group 1 coryneform bacteria and CDC group 1-like coryneform bacteria to the genus Actinomyces as Actinomyces neuil subsp. neuii sp. nov., subsp. nov., and Actinomyces neuii subsp. anitratus subsp. nov. Int. J. Syst. Bacteriol. 44:167-171.

52. Georg, L. K., and J. M. Brown. 1967. Rothia, gen. nov. An aerobic genus of the family Actinomycetaceae. Int. J. Syst. Bacteriol. 17:79-88.

53. Gibbons, N. E., and R. G. E. Murray. 1978. Proposals concerning the higher taxa of bacteria. Int. J. Syst. Bacteriol. 28:1-6.

54. Gledhill, W. E., and L. E. Casida, Jr. 1969. Predominant catalase-negative soil bacteria. III. Agromyces, gen. n., microorganisms intermediary to Actinomyces and Nocardia. Appl. Microbiol. 18:340-349.

55. Gochnauer, M. B., G. G. Leppard, P. Komaratat, M. Kates, T. Novitsky, and D. J. Kushner. 1975. Isolation and characterization of Actinopolyspore halophila, gen. et sp. nov., an extremely halophilic actinomycete. Can. J. Microbiol. 21:1500-1511.

56. Goodfellow, M., L. J. Stanton, K. E. Simpson, and D. E. Minnikin. 1990 Numerical and chemical classification of Actinoplanes and some related actinomycetes. J. Gen. Microbiol. 136:19-36.

57. Greenwood, J. R., and M. J. Pickett. 1980. Transfer of Haemophilus vaginalis Gardner and Dukes to a new genus, Gardnerella: G. vaginalis (Gardner and Dukes) comb. nov. Int. J. Syst. Bacteriol. 30:170-178.

58. Groth, I., P. Schumann, N. Weiss, K. Martin, and F. A. Rainey. 1996 Agrococcus jenensis gen. nov., sp. nov., a new genus of actinomycetes with diaminobutyric acid in the cell wall. Int. J. Syst. Bacteriol. 46:234-239.

59. Gupta, R. S., and G. B. Golding. 1996. The origin of the eukaryotic cell. Trends Biochem. Sci. 21:166-171.

60. Gupta, R. S., and B. Singh. 1992. Cloning of the HSP70 gene from Halobac terium marismortui: relatedness of archaebacterial HSP70 to its eubacteria homologs and a model for the evolution of the HSP70 gene. J. Bacteriol. 174:4594-4605.

61. Haas, F., and H. König. 1988. Coriobacterium glomerans gen. nov., spec. nov. from the intestinal tract of the red soldier bug. Int. J. Syst. Bacteriol. 38:382-384.

62. Hahn, D., M. P. Lechevalier, A. Fischer, and E. Stackebrandt. 1989. Evidence for a close phylogenetic relationship between members of the genera Frankia, Geodermatophilus and Blastococcus and emendation of the family Frankiaceae. Syst. Appl. Microbiol. 11:236-242.

63. Harz, C. O. 1877. Actinomyces bovis, ein neuer Schimmel in den Geweben 
des Rindes. Jahresber. K. Zbl. Thierärz. Sch. München 1877/1888. 5:125140.

64. Hasegawa, T. 1988. Actinokineospora: a new genus of the Actinomycetales Actinomycetes 2:31-45.

65. Hasegawa, T., M. P. Lechevalier, and H. A. Lechevalier. 1978. A new genus of the Actinomycetales: Actinosynnema gen. nov. Int. J. Syst. Bacteriol. 28:304-310.

66. Henssen, A. 1957. Beiträge zur Morphologie und Systematik der thermophilen Actinomyceten. Arch. Mikrobiol. 26:373-416.

67. Huber, R., C. R. Woese, T. A. Langworthy, H. Fricke, and K. O. Stetter 1989. Thermosipho africanus gen. nov. represents a new genus of thermophilic eubacteria within the "Thermotogales." Syst. Appl. Microbiol. 12:3237

68. Inuma, S., A. Yokota, T. Hasegawa, and T. Kanamaru. 1994. Actinocorallia gen. nov., a new genus of the order Actinomycetales. Int. J. Syst. Bacteriol. 44:230-234.

69. Jones, D., and M. D. Collins. 1988. Taxonomic studies on some human cutaneous coryneform bacteria: description of Dermabacter hominus gen. nov., sp. nov. FEMS Microbiol. Lett. 51:51-56.

70. Jukes, T. H., and C. R. Cantor. 1969. Evolution of protein molecules, p. 21-132. In H. N. Munro (ed.), Mammalian protein metabolism. Academic Press, New York, N.Y.

71. Kalakoutskii, L. V., I. P. Kirillova, and N. A. Krasil'nikov. 1967. A new genus of the Actinomycetales-Intrasporangium gen. nov. J. Gen. Microbiol. 48:79-85.

72. Kane, W. D. 1966. A new genus of Actinoplanaceae, Pilimelia, with a description of two species, Pilimelia terevasa and Pilimelia anulata. J. Elisha Mitchell Sci. Soc. 82:220-230.

73. Kim, D., J. Chun, N. Sahin, Y. C. Hah, and M. Goodfellow. 1996. Analysis of thermophilic clades within the genus Streptomyces by $16 \mathrm{~S}$ ribosomal DNA sequence comparisons. Int. J. Syst. Bacteriol. 46:581-587.

74. Kim, S.-B., J.-H. Yoon, H. Kim, S. T. Lee, Y.-H. Park, and M. Goodfellow. 1995. A phylogenetic analysis of the genus Saccharomonospora conducted with 16S rRNA gene sequences. Int. J. Syst. Bacteriol. 4:351-356.

75. Koch, C., R. M. Kroppenstedt, and E. Stackebrandt. 1996. Intrageneric relationships of the actinomycete genus Micromonospora. Int. J. Syst. Bacteriol. 46:383-387.

76. Koch, C., F. A. Rainey, and E. Stackebrandt. 1994. 16S rDNA studies on members of Arthrobacter and Micrococcus, an aid for their future taxonomic restructuring. FEMS Microbiol. Lett. 123:167-172.

77. Koch, C., P. Schumann, and E. Stackebrandt. 1995. Reclassification of Micrococcus agilis Ali-Cohen 1889 to the genus Arthrobacter as Arthrobacter agilis comb. nov, and emendation of the genus Arthrobacter. Int. J. Syst. Bacteriol. 45:837-839.

78. Koch, C., R. M. Kroppenstedt, F. A. Rainey, and E. Stackebrandt. 1996. 16 S ribosomal DNA analysis of the genera Micromonospora, Actinoplanes, $\mathrm{Ca}$ tellatospora, Catenuloplanes, Couchioplanes, Dactylosporangium, and Pilimelia and emendation of the family Micromonosporaceae. Int. J. Syst. Bacteriol. 46:765-768.

79. Korn-Wendisch, F., F. A. Rainey, R. M. Kroppenstedt, A. Kempf, A. Majazza, H. J. Kutzner, and E. Stackebrandt. 1995. Thermocrispum gen. nov., a new genus of the order Actinomycetales, and description of Thermocrispum municipale sp. nov. and Thermocrispum agreste sp. nov. Int. J. Syst. Bacteriol. 45:67-77

80. Krassilnikov, N. A. 1938. Ray fungi and related organisms, Actinomycetales. Akademiya Nauk SSSR, Moscow.

81. Krassilnikov, N. A. 1949. Guide to the bacteria and actinomycetes. Akademiya Nauk SSSR Moscow.

82. Krassilnikov, N. A., L. V. Kalakoutskii, and N. F. Kirillova. 1961. A new genus of ray fungi-Promicromonospora gen. nov. Izv. Akad. Nauk SSSR Ser. Biol. 1:107-112.

83. Kudo, T., T. Itoh, S. Miyadoh, T. Shomura, and A. Seino. 1993. Herbidospora gen. nov., a new genus of the family Streptosporangiaceae Goodfellow et al. 1990. Int. J. Syst. Bacteriol. 43:319-328.

84. Labeda, D. P., R. T. Testa, M. P. Lechevalier, and H. A. Lechevalier. 1984. Saccharothrix, a new genus of the Actinomycetales related to Nocardiopsis. Int. J. Syst. Bacteriol. 34:426-431.

85. Labeda, D. P., R. T. Testa, M. P. Lechevalier, and H. A. Lechevalier. 1985. Glycomyces, a new genus of the Actinomycetales. Int. J. Syst. Bacteriol. 35:417-421.

86. Lacey, J., and M. Goodfellow. 1975. A novel actinomycete from sugar cane bagasse: Saccharopolyspora hirsuta gen. et sp. nov. J. Gen. Microbiol. 88: $78-85$

87. Lassnig, C., M. Dorsch, E. Schaper, H. Stöffier, J. Wolters, and E. Stackebrandt. 1989. Phylogenetic evidence for a relationship of Mobiluncus to the genus Actinomyces. FEMS Microbiol. Lett. 65:17-22.

88. Leblond-Bourget, N., H. Philippe, I. Mangin, and B. Decaris. 1996. $16 \mathrm{~S}$ rRNA and $16 \mathrm{~S}$ to $23 \mathrm{~S}$ internal transcribed spacer sequence analyses reveal inter- and intraspecific Bifidobacterium phylogeny. Int. J. Syst. Bacteriol. 46:102-111.

89. Lechevalier, H. A., and M. P. Lechevalier. 1970. A critical evaluation of the genera of aerobic actinomycetes, p. 393-405. In H. Prauser (ed.), The
Actinomycetales. VEB Gustav Fischer Verlag, Jena, German Democratic Republic

90. Lechevalier, M. P. 1972. Description of a new species, Oerskovia xanthin eolytica, and emendation of Oerskovia Prauser et al. Int. J. Syst. Bacteriol. 22:260-264.

91. Lechevalier, M. P., H. A. Lechevalier, and P. E. Holbert. 1968. Sporichthya, un nouveau genre de Streptomycetaceae. Ann. Inst. Pasteur 114:277-286.

92. Lechevalier, M. P., H. Prauser, D. P. Labeda, and J.-S. Ruan. 1986. Two new genera of nocardioform actinomycetes: Amycolata gen. nov. and Amycolatopsis gen. nov. Int. J. Syst. Bacteriol. 36:29-37.

93. Lechevalier, M. P., M. Solotorovsky, and C. I. McDurmont. 1961. A new genus of Actinomycetales: Micropolyspora gen. nov. J. Gen. Microbiol. 26 11-18.

94. Lehmann, K. B., and R. Neumann. 1896. Atlas und Grundriss der Bakteriologie und Lehrbuch der speziellen bakteriologischen Diagnostik, 1st ed. J. F. Lehmann, Munich, Germany.

95. Lehmann, K. B., and R. Neumann. 1907. Lehmann's Medizin Handatlanten. X. Atlas und Grundriss der Bakteriologie und Lehrbuch der speziellen bakteriologischen Diagnostik, 4th ed. J. F. Lehmann, Munich, Ger many.

96. Ludwig, W., and K.-H. Schleifer. 1994. Bacterial phylogeny based on 16S and $23 S$ rRNA sequence analysis. FEMS Microbiol. Rev. 15:155-173.

97. Ludwig, W., J. Neumaier, N. Klugbauer, E. Brockmann, C. Roller, S. Jilg K. Reetz, I. Schachtner, A. Ludvigsen, M. Bachleitner, U. Fischer, and K.-H. Schleifer. 1993. Phylogenetic relationships of Bacteria based on comparative sequence analysis of elongation factor Tu and ATP-synthase $b$ subunit genes. Antonie Leeuwenhoek 64:285-305.

98. Luedemann, G. 1968. Geodermatophilus, a new genus of the Dermatophilaceae (Actinomycetales). J. Bacteriol. 96:1848-1858.

99. Maidak, B. L., N. Larsen, M. J. McCaughey, R. Overbeek, G. J. Olsen, K Fogel, J. Blandy, and C. R. Woese. 1994. The Ribosomal Database Project. Nucleic Acids Res. 22:3485-3487.

100. Meyer, J. 1976. Nocardiopsis, a new genus of the order Actinomycetales. Int J. Syst. Bacteriol. 26:487-493

101. Miller, E. S., C. R. Woese, and S. Brenner. 1991. Description of the erythromycin-producing bacterium Arthrobacter sp. strain NRRL B-3381 as Aeromicrobium erythreum gen. nov., sp. nov. Int. J. Syst. Bacteriol. 41:363Aerom.

102. Mohagheghi, A., K. Grohmann, M. Himmel, L. Leighton, and D. M. Up degraff. 1986. Isolation and characterization of Acidothermus cellulolyticus gen. nov., sp. nov., a new genus of thermophilic, acidophilic, cellulolytic bacteria. Int. J. Syst. Bacteriol. 36:435-443.

103. Nakamura, K., A. Hiraishi, Y. Yoshimi, M. Kawaharasaki, K. Masuda, and Y. Kamagata. 1995. Microlunatus phosphovorus gen. nov., sp. nov., a new gram-positive polyphosphate-accumulating bacterium isolated from activated sludge. Int. J. Syst. Bacteriol, 45:17-22.

104. Nesterenko, O., E. I. Krassilnikov, and T. M. Nogina. 1985. Nocardioi daceae fam. nov., a new family of the order Actinomycetales Buchanan 1917. Mikrobiol. Zh. 47:3-12.

105. Nonomura, H., and Y. Ohara. 1957. Distribution of actinomycetes in soil II. Microbispora, a new genus of Streptomycetaceae. J. Ferment. Technol 35:307-311.

106. Nonomura, H., and Y. Ohara. 1971. Distribution of actinomycetes in soil. $\mathrm{X}$. New genus and species of monosporic actinomycetes. J. Ferment. Technol. 49:895-903.

107. Normand, P., S. Orso, B. Cournover, P. Jeannin, C. Chapelon, J. Dawson, L. Evtushenko, and A. K. Misra. 1996. Molecular phylogeny of the genus Frankia and related genera and emendation of the family Frankiaceae. Int. J. Syst. Bacteriol. 46:1-9.

108. Orla-Jensen, S. 1909. Die Hauptlinien des natürlichen Bakteriensystems. Zentralbl. Bakteriol. Parasitenkd. Infektionskr. Hyg. Abt. 2 22:305-346.

109. Orla-Jensen, S. 1919. The lactic acid bacteria. Høst and Son, Copenhagen, Denmark.

110. Orla-Jensen, S. 1924. La classification des bactéries lactiques. Lait 4:468474.

111. Ørskov, J. 1923. Investigations into the morphology of the Ray Fungi. Levin and Munksgaard, Copenhagen, Denmark.

112. Pagani, H., and F. Parenti. 1978. Kineosporia, a new genus of the order Actinomycetales. Int. J. Syst. Bacteriol. 28:401-406.

113. Park, Y. H., K. Suzuki, D. G. Yim, K. C. Lee, J. Yoon, S. Kim, Y. H. Kho, M. Goodfellow, and K. Komagata. 1993. Suprageneric classification of peptidoglycan group B actinomycetes by sequencing of 5 S ribosomal RNA. Antonie Leeuwenhoek 64:307-313.

114. Pascual, C., P. A. Lawson, J. A. E. Farrow, M. N. Gimenez, and M. D. Collins. 1995. Phylogenetic analysis of the genus Conyebacterium based on 16S rRNA gene sequences. Int. J. Syst. Bacteriol. 45:724-728.

115. Pitulle, C., M. Dorsch, J. Kazda, J. Wolters, and E. Stackebrandt. 1992 Phylogeny of rapidly growing members of the genus Mycobacterium. Int. J. Syst. Bacteriol. 42:337-343.

116. Prauser, H. 1976. Nocardioides, a new genus of the order Actinomycetales. Int. J. Syst. Bacteriol. 26:58-65.

117. Prauser, H., M. P. Lechevalier, and H. A. Lechevalier. 1970. Description of 
Oerskovia gen. n. to harbor Ørskov's motile Nocardia. Appl. Microbiol. 19:534

118. Prévot, A. R. 1940. Manuel de classification et de détermination des bactéries anaérobies, 1st ed. Masson, Paris, France.

119. Prévot, A. R. 1953. Classification, embranchement, sous-embranchements, classes, ordres, familles, tribus et genres d'apres, p. 692. In P. Hauduroy, G. Ehringer, G. Guillot, J. Magrou, A. R. Prévot, A. Rosset, and A. Urbain (ed.), Dictionnaire des bactéries pathogènes, 2nd ed. Masson, Paris, France.

120. Prévot, A. R. 1961. Traité de systematique bactérienne. Dunod, Paris, France.

121. Pribham, E. 1929. A contribution to the classification of microorganisms. J. Bacteriol. 18:361-394.

122. Rainey, F., N. Weiss, H. Prauser, and E. Stackebrandt. 1994. Further evidence for the phylogenetic coherence of actinomycetes with group Bpeptidoglycan and evidence for the phylogenetic intermixing of the genera Microbacterium and Aureobacterium as determined by $16 \mathrm{~S}$ rRNA analysis. FEMS Microbiol. Lett. 118:135-140.

123. Rainey, F. A., and E. Stackebrandt. 1993. Phylogenetic evidence for the classification of Acidothermus cellulolyticus into the subphylum of actinomycetes. FEMS Microbiol. Lett. 108:27-30.

124. Rainey, F. A., J. Burghardt, R. M. Kroppenstedt, S. Klatte, and E. Stackebrandt. 1995. Phylogenetic analysis of the genera Rhodococcus and Nocardia and evidence for the evolutionary origin of the genus Nocardia from within the radiation of Rhodococcus species. Microbiology (Reading) 141: 523-528.

125. Rainey, F. A., S. Klatte, R. M. Kroppenstedt, and E. Stackebrandt. 1995 Dietzia, a new genus including Dietzia maris comb. nov., formerly Rhodococcus maris. Int. J. Syst. Bacteriol, 45:32-36.

126. Rainey, F. A., P. Schumann, H. Prauser, R. Toalster, and E. Stackebrandt. 1993. Sporichthya polymorpha represents a novel line of descent within the order Actinomycetales. FEMS Microbiol. Lett. 109:263-269.

127. Rainey, F. A., N. Ward-Rainey, R. M. Kroppenstedt, and E. Stackebrandt 1996. The genus Nocardiopsis represents a phylogenetically coherent taxon and a distinct actinomycete lineage: Proposal of Nocardiopsaceae fam. nov. Int. J. Syst. Bacteriol. 46:1088-1092.

128. Rainey, F. A., N. Weiss, and E. Stackebrandt. 1994. Coriobacterium and Atopobium are phylogenetic neighbors within the actinomycetes line of descent. Syst. Appl. Microbiol. 17:202-205.

129. Rainey, F. A., N. Weiss, and E. Stackebrandt. 1995. Phylogenetic analysis of the genera Cellulomonas, Promicromonospora, and Jonesia and proposal to exclude the genus Jonesia from the family Cellulomonadaceae. Int. J. Syst. Bacteriol. 45:649-652.

130. Rocourt, J., U. Wehmeyer, and E. Stackebrandt. 1987. Transfer of Listeria denitrificans into a new genus Jonesia gen. nov. as Jonesia denitrificans comb. nov. Int. J. Syst. Bacteriol. 37:266-270.

131. Rogall, T., J. Wolters, T. Flohr, and E. Böttger. 1990. Towards a phylogeny and the definition of species at the molecular level within the genus $\mathrm{Myco}$ bacterium. Int. J. Syst. Bacteriol. 40:323-330.

132. Roller, C., W. Ludwig, and K. H. Schleifer. 1992. Gram-positive bacteria with a high $\mathrm{G}+\mathrm{C}$ content are characterized by a common insertion within their 23S rRNA genes. J. Gen. Microbiol. 138:1167-1175.

133. Roller, C., M. Wagner, R. Amann, W. Ludwig, and K.-H. Schleifer. 1994. In situ probing of Gram-positive bacteria with high DNA G+C content using 23S rRNA-targeted oligonucleotides. J. Gen. Microbiol. 140:2859-2865.

134. Ruimy, R., P. Boiron, V. Boivin, and R. Christen. 1994. A phylogeny of the genus Nocardia deduced from the analysis of small-subunit ribosomal DNA sequences, including transfer of Nocardia amarae to the genus Gordona as Gordona amarae comb. nov. FEMS Microbiol. Lett. 123:261-268.

135. Ruimy, R., P. Riegel, P. Boiron, H. Monteil, and R. Christen. 1995. Phy logeny of the genus Corynebacterium deduced from analysis of small-subunit ribosomal DNA sequences. Int. J. Syst. Bacteriol. 45:740-746.

136. Saitou, N., and M. Nei. 1987. The neighbor-joining method: a new method for reconstructing phylogenetic trees. Mol. Biol. Evol. 4:406-425.

137. Sanders, J. E., and J. L. Fryer. 1980. Renibacterium salmoninarum gen nov., sp. nov., the causative agent of bacterial kidney disease in salmonid fishes. Int. J. Syst. Bacteriol. 30:496-502.

138. Schlesner, H., and E. Stackebrandt. 1986. Assignment of the genera Planctomyces and Pirella to a new family Planctomycetaceae fam. nov. and description of the order Planctomycetales ord. nov. Syst. Appl. Microbiol. 8:174-176.

139. Schubert, K., W. Ludwig, N. Springer, R. M. Kroppenstedt, J.-P. Accolas, and F. Fiedler. 1996. Two coryneform bacteria isolated from the surface of French Gruyère and Beaufort cheeses are new species of the genus Brachybacterium: Brachybacterium alimentarium sp. nov. and Brachybacterium ty rofermentans sp. nov. Int. J. Syst. Bacteriol. 46:81-87.

140. Shearer, M. C., P. M. Colman, R. M. Ferrin, L. J. Nisbet, and C. H. Nash III. 1986. A new genus of the Actinomycetales: Kibdelosporangium aridum gen. nov., sp. nov. Int. J. Syst. Bacteriol. 36:47-54.

141. Spiegel, C. A., and M. Roberts. 1984. Mobiluncus gen. nov., Mobiluncus curtisii subsp. curtesii sp. nov., Mobiluncus curtisii subsp. holmesii subsp. nov, and Mobiluncus mulieris sp. nov., curved rods from the human vagina. Int. J. Syst. Bacteriol. 34:177-184.

142. Stackebrandt, E., and O. Charfreitag. 1990. Partial 16S rRNA primary structure of five Actinomyces species: phylogenetic implications and development of an Actinomyces israelii-specific oligonucleotide probe. J. Gen. Microbiol. 136:37-43.

143. Stackebrandt, E., and B. M. Goebel. 1994. A place for DNA-DNA reassociation and 16S rRNA sequence analysis in the present species definition in bacteriology. Int. J. Syst. Bacteriol. 44:846-849.

144. Stackebrandt, E., and O. Kandler. 1979. Taxonomy of the genus Cellulomonas, based on phylogenetic characters and deoxyribonucleic acid-deoxyribonucleic acid homology, and proposal of seven neotype strains. Int. J. Syst. Bacteriol. 29:273-282.

145. Stackebrandt, E., and R. Kroppenstedt. 1987. Union of the genera Actinoplanes Couch, Ampullariella Couch, and Amorphosporangium in a redefined genus Actinoplanes. Syst. Appl. Microbiol. 9:110-114.

146. Stackebrandt, E., and W. Ludwig. 1994. The importance of using outgroup reference organisms in phylogenetic studies, the Atopobium case. Syst. Appl. Microbiol. 17:39-43.

147. Stackebrandt, E., and H. Prauser. 1991. Assignment of the genera Cellulomonas, Oerskovia, Promicromonospora and Jonesia into Cellulomonadaceae family nov. Syst. Appl. Microbiol. 14:261-265.

148. Stackebrandt, E., B. J. Lewis, and C. R. Woese. 1980. The phylogenetic structure of the coryneform group of bacteria. Zbl. Bakt. Abt. 1 Orig. C 2:137-149.

149. Stackebrandt, E., W. Liesack, and B. M. Goebel. 1993. Bacterial diversity in a soil sample from a subtropical Australian environment as determined by 16S rDNA analysis. FASEB J. 7:232-236.

150. Stackebrandt, E., C. Koch, O. Gvozdiak, and P. Schumann. 1995. Taxonomic dissection of the genus Micrococcus: Kocuria gen. nov., Nesterenkonia gen. nov., Kytococcus gen. nov., Dermacoccus gen. nov., and Micrococcus Cohn 1872 gen. emend. Int. J. Syst. Bacteriol. 45:682-692.

151. Stackebrandt, E., R. Kroppenstedt, and V. Fowler. 1983. A phylogenetic analysis of the family Dermatophilaceae. J. Gen. Microbiol. 129:1831-1838.

152. Stackebrandt, E., R. M. Kroppenstedt, K.-D. Jahnke, C. Kemmerling, and H. Gürtler. 1994. Transfer of Streptosporangium viridogriseum (Okuda et al. 1966). Streptosporangium viridogriseum subsp. kofuense (Nonomura and Ohara 1969), and Streptosporangium albidum (Furumai et al. 1968) to Kutzneria gen. nov. as Kutzneria viridogrisea comb. nov., Kutzneria kofuensis comb. nov., and Kutzneria albida comb. nov., respectively, and emendation of the genus Streptosporangium. Int. J. Syst. Bacteriol. 44:265-269.

153. Stackebrandt, E., H. Seiler, and K.-H. Schleifer. 1982. Union of the genera Cellulomonas Bergey et al. and Oerskovia Prauser et al. in a redefined genus Cellulomonas. Zbl. Bakt. Hyg. Abt. 1 Orig. C 3:401-409.

154. Stackebrandt, E., J. Smida, and M. D. Collins. 1988. Evidence of phylogenetic heterogeneity within the genus Rhodococcus, revival of the genus Gordona Tsukamura. J. Appl. Microbiol. 34:341-348.

155. Stackebrandt, E., D. Witt, C. Kemmerling, R. Kroppenstedt, and W. Liesack. 1991. Designation of streptomycete $16 \mathrm{~S}$ and 23S rRNA-based target regions for oligonucleotide probes. Appl. Environ. Microbiol. 57:14681477

156. Strunk, O., and W. Ludwig. 1995. ARB-a software environment for sequence data. Department of Microbiology, Technical University of Munich Munich, Germany. (E-mail: arb@mikro.biologie.tu-muenchen.de.)

157. Suzuki, K., M. D. Collins, E. Iijiama, and K. Komagata. 1988. Chemotaxonomic characterization of a radiotolerant bacterium, Arthrobacter radiotolerans: description of Rubrobacter radiotolerans gen. nov., comb. nov. FEMS Microbiol. Lett. 52:33-40.

158. Suzuki, K. I., J. Sasaki, M. Uramoto, T. Nakase, and K. Komagata. 1996. Agromyces mediolanus sp. nov., nom. rev., comb. nov., a species for "Corynebacterium mediolanum" Mamoli 1939 and for some aniline-assimilating bacteria which contain 2,4-diaminobutyric acid in the cell wall peptidoglycan. Int. J. Syst. Bacteriol. 46:88-93.

159. Takeuchi, M., and A. Yokota. 1994. Phylogenetic analysis of the genus Microbacterium based on 16S rRNA gene sequences. FEMS Microbiol. Lett. 24:11-16.

160. Takeuchi, T., H. Sawada, F. Tanaka, and I. Matsuda. 1996. Phylogenetic analysis of Streptomyces spp. causing potato scab based on 16S rRNA sequences. Int. J. Syst. Bacteriol. 46:476-479.

161. Tamura, T., and A. Yokota. 1994. Transfer of Nocardioides fastidiosum Collins and Stackebrandt 1989 to the genus Aeromicrobium fastidiosum comb. nov. Int. J. Syst. Bacteriol. 44:608-611.

162. Tamura, T., Y. Nakagaito, T. Nishii, T. Hasegawa, E. Stackebrandt, and A Yokota. 1994. A new genus of the order Actinomycetales, Couchioplane gen. nov., with description of Couchioplanes caeruleus Horan and Brodsky 1986 comb. nov. and Couchioplanes caeruleus subsp. azureus subsp. nov. Int J. Syst. Bacteriol. 44:193-203.

163. Tamura, T., M. Takeuchi, and A. Yokota. 1994. Luteococcus japonicus gen nov., sp. nov., a new gram-positive coccus with LL-diaminopimelic acid in the cell wall. Int. J. Syst. Bacteriol. 44:348-356.

164. Thiemann, J. E., and G. Beretta. 1968. A new genus of the Actinoplanaceae Planobispora, gen. nov. Arch. Mikrobiol. 62:157-166. 
165. Thiemann, J. E., H. Pagani, and G. Beretta. 1967. A new genus of the Actinoplanaceae. Dactylosporangium, gen. nov. Arch. Mikrobiol. 58:42-52.

166. Thiemann, J. E., H. Pagani, and G. Beretta. 1967. A new genus of the Actinoplanaceae. Planomonospora, gen. nov. Giornale Microbiol. 15:27-28.

167. Thiemann, J. E., H. Pagani, and G. Beretta. 1968. A new genus of Actinomycetales. Microtetraspora, gen. nov. J. Gen. Microbiol. 50:295-303.

168. Tomita, K., Y. Nakakita, Y. Hoshino, K. Numata, and H. Kawaguchi. 1987. New genus of the Actinomycetales: Streptoalloteichus hindustanus gen. nov. nom. rev.; sp. nov., nom. rev. Int. J. Syst. Bacteriol. 37:211-213.

169. Trevisan, v. 1889. I generi e le specie delle Batteriaceae. Zanaboni and Gabuzzi, Milan, Italy.

170. Van Saceghem, R. 1915. Dermatose contagieuse (impétigo contagieux). Bull. Soc. Pathol. Exot. 8:354-359.

171. Waksman, S. A., and A. T. Henrici. 1943. The nomenclature and classification of the actinomycetes. J. Bacteriol. 46:337-341.

172. Wang, Y., Z. Zhang, and J. Ruan. 1996. Phylogenetic analysis reveals new relationships among members of the genera Microtetraspora and Microbispora. Int. J. Syst. Bacteriol. 46:658-663.

173. Ward-Rainey, N., F. A. Rainey, H. Schlesner, and E. Stackebrandt. 1995. Assignment of hitherto unidentified 16S rDNA species to a main line of descent within the domain Bacteria. Microbiology 141:3247-3250.

174. Ward-Rainey, N., F. A. Rainey, and E. Stackebrandt. 1996. The phylogenetic structure of the genus Streptosporangium. Syst. Appl. Microbiol. 19: 50-55.

175. Warwick, S., T. Bowen, H. McVeigh, and T. M. Embley. 1994. A phylogenetic analysis of the family Pseudonocardiaceae and the genera Actinokineospora and Saccharothrix with 16S rRNA sequences and a proposal to combine the genera Amycolata and Pseudonocardia in an emended genus Pseudonocardia. Int. J. Syst. Bacteriol. 44:293-299.

176. Wellington, E. M. H., E. Stackebrandt, D. Sanders, J. Wolstrup, and N. O. G. Jorgensen. 1992. Taxonomic status of Kitasatosporia, and proposed unification with Streptomyces on the basis of phenotypic and 16S rRNA analysis and emendation of Streptomyces Waksman and Henrici $1943^{\mathrm{AL}}$. Int. J. Syst. Bacteriol. 42:156-160.

177. Wheelis, M. L., O. Kandler, and C. R. Woese. 1992. On the nature of global classification. Proc. Natl. Acad. Sci. USA 89:2930-2934.

178. Witt, D., and E. Stackebrandt. 1990. Unification of the genera Streptoverticillum and Streptomyces, and amendation of Streptomyces Waksman and
Henrici 1943, 339 AL. Syst. Appl. Microbiol. 13:361-371.

179. Woese, C. R. 1987. Bacterial evolution. Microbiol. Rev. 51:221-271.

180. Woese, C. R., O. Kandler, and M. L. Wheelis. 1990. Towards a natura system of organisms. Proposal for the domains Archaea, Bacteria, and Eucarya. Proc. Natl. Acad. Sci. USA 87:4576-4579.

181. Yamada, K., and K. Komagata. 1972. Taxonomic studies on coryneform bacteria. IV. Morphological, cultural, biochemical and physiological characteristics. J. Gen. Appl. Microbiol. 18:399-416.

182. Yamamoto, N., S.-I. Sato, K. Saito, T. Hasuo, M. Tadenuma, K.-I. Suzuki, J. Tamaoka, and K. Komagata. 1988. Rarobacter faecitabidus gen. nov., sp. nov., a yeast-lysing coryneform bacterium. Int. J. Syst. Bacteriol. 38:7-11.

183. Yassin, A. F., F. A. Rainey, H. Brzezinka, J. Burghardt, M. Rafai, P. Seifert K. Feldmann, and K. P. Schaal. 1996. Tsukamurella pulmonis sp. nov. Int J. Syst. Bacteriol. 46:429-436.

184. Yassin, A. F., F. A. Rainey, H. Brzezinka, K.-D. Jahnke, H. Weissbrodt, H Budzikiewicz, E. Stackebrandt, and K. P. Schaal. 1995. Lentzea gen. nov., a new genus of the order Actinomycetales. Int. J. Syst. Bacteriol. 45:357-363.

185. Yokota, A., T. Tamura, T. Hasegawa, and L. H. Huang. 1993. Catenulo planes japonicus gen. nov., sp. nov., nom. rev., a new genus of the order Actinomycetales. Int. J. Syst. Bacteriol. 43:805-812.

186. Yokota, A., T. Tamura, T. Nishii, and T. Hasegawa. 1993. Kineococcu aurantiacus gen. nov., sp. nov., a new aerobic, gram-positive, motile coccus with meso-diaminopimelic acid and arabinogalactan in the cell wall. Int. J. Syst. Bacteriol. 43:52-57.

187. Yokota, A., T. Tamura, N. Weiss, and E. Stackebrandt. 1994. Transfer of Propionibacterium innocuum Pitcher and Collins 1991 to Propioniferax gen. nov. as Propioniferax innocuum comb. nov. Int. J. Syst. Bacteriol. 44:579 582 .

188. Yoshimi, Y., A. Hiraishi, and K. Nakamura. 1996. Isolation and characterization of Microsphaera multipartita gen. nov., sp. nov., a polysaccharideaccumulating gram-positive bacterium from activated sludge. Int. J. Syst. Bacteriol. 46:519-525.

189. Zgurskaya, H. I., L. I. Evtushenko, V. N. Akimov, and L. V. Kalakoutskii 1993. Rathayibacter gen. nov., including the species Rathayibacter rathay comb. nov., Rathayibacter tritici comb. nov., Rathayibacter iranicus comb. nov., and six strains from annual grasses. Int. J. Syst. Bacteriol. 43:143-149.

190. Zopf, W. 1891. Uber Ausscheidung von Fettfarbstoffen Lipochromen seitens gewisser Spaltpilze. Ber. Dtsch. Bot. Ges. 9:22-29. 